\title{
Record of Decision/Remedial Alternative Selection for the Motor Shops Seepage Basin (716-A)
}

by

E. Palmer

Westinghouse Savannah River Company

Savannah River Site

Aiken, South Carolina 29808

\section{RECEIVED}

FEB 121999

OSTI

DOE Contract No. DE-AC09-96SR18500

This paper was prepared in connection with work done under the above contract number with the U.S.

Department of Energy. By acceptance of this paper, the publisher and/or recipient acknowledges the U. S. Government's right to retain a nonexclusive, royalty-free license in and to any copyright covering this paper, along with the right to reproduce and to authorize others to reproduce all or part of the copyrighted paper. 


\section{United States Department of Energy}

Savannah River Site

\section{Record of Decision}

\section{Remedial Alternative Selection for the \\ Motor Shops Seepage Basin (716-A) (U)}

WSRC-RP-97-840

Revision 0

April 1998

Westinghouse Savannah River Company

Savannah River Site

Aiken, SC 29808

Prepared for the U. S. Department of Energy under Contract No. DE-AC09-96-SA18500

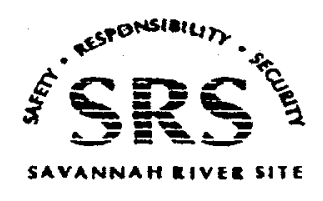




\section{DISCLAIMER}

This report was prepared as an account of work sponsored by an agency of the United States Government. Neither the United States Government nor any agency thereof, nor any of their employees, makes any warranty, express or implied, or assumes any legal liability or responsibility for the accuracy, completeness, or usefulness of any information, apparatus, product, or process disclosed, or represents that its use would not infringe privately owned rights. Reference herein to any specific commercial product, process, or service by trade name, trademark, manufacturer, or otherwise does not necessarily constitute or imply its endorsement, recommendation, or favoring by the United States Government or any agency thereof. The views and opinions of authors expressed herein do not necessarily state or reflect those of the United States Government or any agency thereof.

This report has been reproduced directly from the best available copy.

Available to DOE and DOE contractors from the Office of Scientific and Technical Information, P.O. Box 62, Oak Ridge, TN 37831; prices available from (615) 576-8401.

Available to the public from the National Technical Information Service, U.S. Department of Commerce; 5285 Port Royal Road, Springfield, VA 22161. 


\section{DISCLAIMER}

Portions of this document may be illegible in electronic image products. Images are produced from the best available original document. 


\title{
RECORD OF DECISION
}

\author{
REMEDIAL ALTERNATIVE SELECTION
}

FOR THE MOTOR SHOPS SEEPAGE BASIN (716-A) (U)

\section{WSRC-RP-97-840}

Revision 0

April 1998

Savannah River Site

Aiken, South Carolina

\author{
Prepared by: \\ Westinghouse Savannah River Company \\ for the \\ U.S. Department of Energy Under Contract DE-AC09-96SR1 8500 \\ Savannah River Operations Office \\ Aiken, South Carolina
}


Record of Decision for the Motor Shops Seepage Basin (716-A) (U)

WSRC-RP-97-840

Savannah River Site

Revision 0

April 1998

This page intentionally left blank. 


\section{DECLARATION FOR THE RECORD OF DECISION}

\section{Unit Name and Location}

Motor Shops Seepage Basin (716-A)

Savannah River Site

Aiken, South Carolina

The Motor Shops Seepage Basin (716-A) (MSSB) is listed as a Resource Conservation and Recovery Act (RCRA) 3004(u) solid waste management unit/Comprehensive Environmental Response, Compensation, and Liability Act (CERCLA) unit in Appendix C of the Federal Facility Agreement (FFA) (FFA 1993) for the Savannah River Site (SRS).

\section{Statement of Basis and Purpose}

This decision document presents the selected remedial alternative for the MSSB located at the Savannah River Site (SRS) in Aiken, South Carolina. The selected alternative was developed in accordance with CERCLA, as amended, and to the extent practicable, the National Oil and Hazardous Substances Pollution Contingency Plan (NCP). This decision is based on the Administrative Record File for this specific RCRA/CERCLA operable unit.

\section{Description of the Selected Remedy}

The selected remedy for MSSB is No Action. Investigation of this operable unit was performed to determine if hazardous substances had been released to the environment. The Baseline Risk Assessment indicated that there were no significant releases to the environment. Therefore, it appears that either there were no significant discharges of hazardous materials to the seepage basin or natural remediation processes (i.e., bioremediation) have reduced the levels of hazardous materials to the extent that they no longer pose risk to human health or the environment.

The Baseline Risk Assessment considered both the future residential and future industrial land use scenarios. Benzo(a)pyrene was the only preliminary constituent of concern (human health) detected in the soil at MSSB. Benzo(a)pyrene was detected only in the top foot of soil at levels which give risk values greater than $1 \times 10^{-6}$ (but less than $1 \times 10^{-4}$ ) for the future adult/child resident. Further uncertainty analysis indicated that benzo(a)pyrene should not be considered a constituent of concern for the MSSB due to: 1) low frequency of detection, 2) unit history that strongly suggests it came from an adjacent source, and 3) conservative methodology was utilized in the risk assessment. No ecological or contaminant migration constituents of concern were identified at this unit. Therefore, No Action is the appropriate remedy and a five year ROD review will not be required. The South Carolina Department of Health and Environmental Control has modified the SRS RCRA permit to incorporate the No Action remedy.

\section{Declaration Statement}

Based on the MSSB Resource Conservation and Recovery Act Facility Investigation/Remedial Investigation (RFI/RI) Report and the Baseline Risk Assessment, the MSSB poses no significant risk to the environment and to human health. It is, therefore, proposed that No Action be performed at the MSSB. The selected remedy is protective of human health and the environment and complies with Federal and State requirements that are legally applicable or relevant and appropriate to the remedial action. Since there is no current or potential threat to human health and the environment and No Action is warranted, the CERCLA 121 requirements are not triggered. 


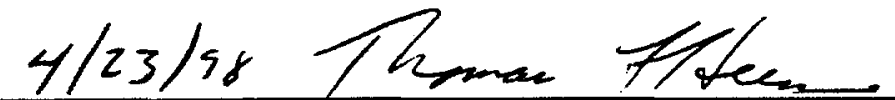

Date

Thomas F. Heenan

Assistant Manager for Environmental Quality

U.S. Department of Energy, Savannah River Operations Office

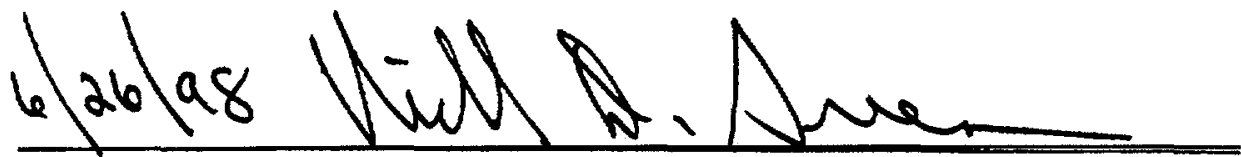

Date Richard D. Green

Division Director

Waste Management Division

U. S. Environmental Protection Agency - Region IV

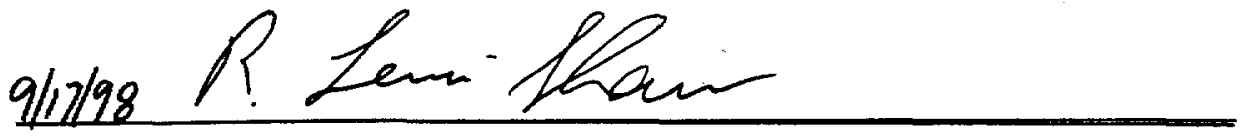

Date

R. Lewis Shaw

Deputy Commissioner

Environmental Quality Control

South Carolina Department of Health and Environmental Control 
DECISION SUMMARY

REMEDIAL ALTERNATIVE SELECTION

FOR THE MOTOR SHOPS SEEPAGE BASIN (716-A) (U)

WSRC-RP-97-840

Revision 0

April 1998

Savannah River Site

Aiken, South Carolina

Prepared by:

Westinghouse Savannah River Company

for the

U.S. Department of Energy Under Contract DE-AC09-96SR 18500

Savannah River Operations Office

Aiken, South Carolina 
Record of Decision for the Motor Shops Seepage Basin (716-A) (U)

Savannah River Site

WSRC-RP-97-840

Aprii 1998

Revision 0

Page ii of vi

This page intentionally left blank. 


\section{DECISION SUMMARY}

TABLE OF CONTENTS

\section{Section}

TABLE OF CONTENTS

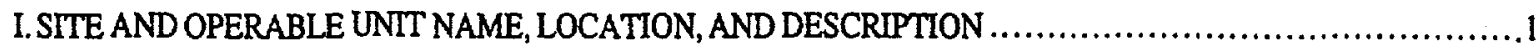

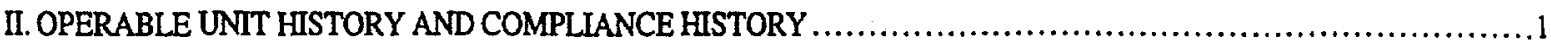

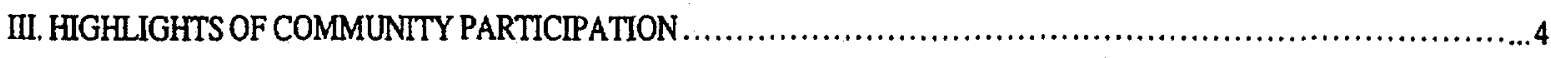

IV. SCOPE AND ROLE OF OPERABLE UNIT WTTHIN THE SITE STRATEGY $\ldots \ldots \ldots \ldots \ldots \ldots \ldots \ldots \ldots \ldots \ldots .5$

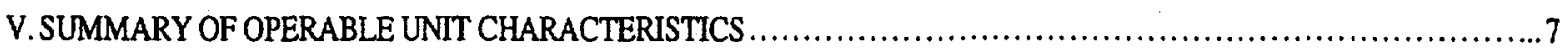

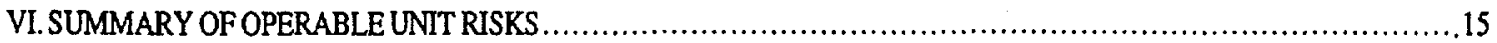

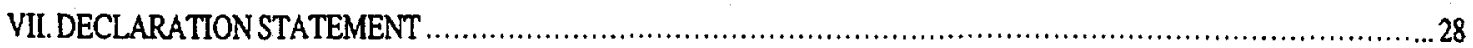

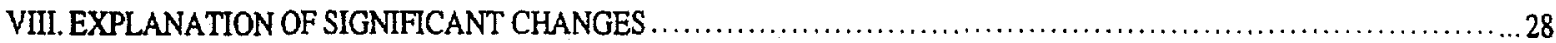

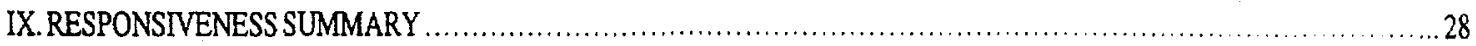

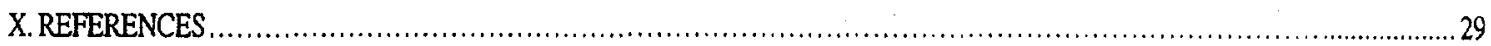

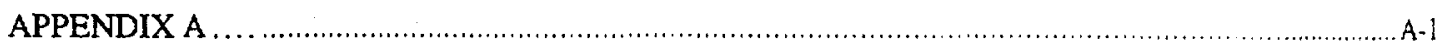




\section{List of Figures}

Figure 1. Location of MSSB at the Savannah River Site

Figure 2. Location of MSSB in the A Area of SRS With Unit Background Sample Locations...................

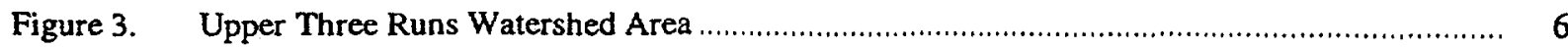

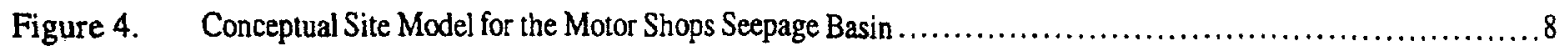

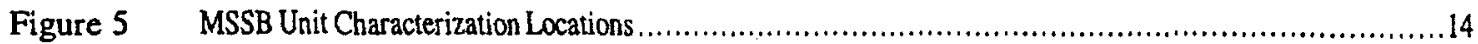

Figure 6. Summary of Risks and Hazards for the MSSB Surface Soil (0-0.3 m) Pathway for the Known On-Unit Worker.

Figure 7. Summary of Risks and Hazards for the MSSB Surface Soil (0-0.3 m) Pathway for the Hypothetical Industrial Worker

Figure 8. Summary of Risks and Hazards for the MSSB Subsurface Soil (0-1.2 m) Pathway for the Hypothetical Industrial Worker

Figure 9. Summary of Risks and Hazards for the MSSB Surface Soil (0-0.3 m) Pathway for the Hypothetical Adult/Child Resident.

Figure 10. Summary of Risks and Hazards for the MSSB Subsurface Soil (0-1.2 m) Pathway for the Hypothetical Adulu/Child Resident.

\section{List of Tables}

Table 1. Summary of Analytes Detected in Background Surface (0-0.3 $\mathrm{m}[0-1 \mathrm{ft}])$ Soil Samples

Table 2. Summary of Analytes Detected in 716-A Motor Shops Seepage Basin Surface (0-0.3 m [0-1 ft]] Soils.

Table 3. Summary of Analytes Detected in Background Subsurface (0-1.2 m [0-4ft]) Soil Samples......12

Table 4. Summary of Analytes Detected in Subsurface (0-1.2 $\mathrm{m}[0-4 \mathrm{ft}])$ Soils .

Table 5. RME Risk Characterization Summary, Surface Soil (Depth 0-0.3 $\mathrm{m}$ [0 to $1 \mathrm{ft}]$ ) at the Motor Shops Seepage Basin.

Table 6. RME Risk Characterization Summary, Subsurface Soil (Depth 0-1.2 m [0 to $4 \mathrm{ft}$ ) at the Motor Shops Seepage Basin. 


\section{List of Acronyms and Abbreviations}

ARAR

bls

CERCLA

DOE

ELCR

EPA

ERA

FFA

HI

HQ

MSSB

NPDES

PAH

PCB

RBA

RBC

RCRA

RfD

RFI

RFI/RI

RME

SCDHEC

SCHWMR

SRS

SWMU
Applicable or Relevant and Appropriate Requirements

Below land surface

Comprehensive Environmental Response, Compensation, and Liability Act

U. S. Department of Energy

Excess Lifetime Cancer Risk

Environmental Protection Agency

Ecological Risk Assessment

Federal Facility Agreement

Hazard Index

Hazard Quotient

Motor Shops Seepage Basin (716-A)

National Pollutant Discharge Elimination System

Polynuclear Aromatic Hydrocarbon

Polychlorinated Biphenyl

Risk-Based Activities

Risk-Based Concentration

Resource Conservation and Recovery Act

Reference Dose

RCRA Facility Investigation

RCRA Facility Investigation/Remedial Investigation

Reasonable Maximum Exposure

South Carolina Department of Health and Environmental Control

South Carolina Hazardous Waste Management Regulations

Savannah River Site

Solid Waste Management Unit 
Record of Decision for the Motor Shops Seepage Basin (716-A) (U)

WSRC-RP-97-840

Savannah River Site

Revision 0

April 1998

Page vi of vi

TBC

To Be Considered

USC

Unit Specific Constituents

WSRC

Westinghouse Savannah River Company 


\section{SITE AND OPERABLE UNIT NAME, LOCATION, AND DESCRIPTION}

Savannah River Site (SRS) occupies approximately 800 square kilometers ( 310 square miles) of land adjacent to the Savannah River, principally in Aiken and Barnwell counties of South Carolina (see Figure 1). SRS is a secured U.S. Government facility with no permanent residents. SRS is located approximately 40 kilometers (25 miles) southeast of Augusta, Georgia and 32 kilometers (20 miles) south of Aiken, South Carolina.

SRS is owned by the U.S. Department of Energy (DOE). Management and operating services are provided by Westinghouse Savannah River Company (WSRC). SRS has historically produced tritium, plutonium, and other special nuclear materials for national defense.

The Motor Shops Seepage Basin (716-A) (MSSB) is located in A Area south of the railroad tracks near the automotive shop (Building 716-A) (see Figure 2) in Aiken County. The elevation varies between 104-107 m (340-350 ft) above mean sea level and slopes gently to the southwest. A small drainage feature runs through the area approximately $91 \mathrm{~m}$ ( $300 \mathrm{ft}$ ) to the east of the MSSB. The headwater is a former National Pollutant Discharge Elimination System (NPDES)-permitted outfall (A-011). This drainage feature turns southwest and discharges into a tributary of Tims Branch. Tims Branch discharges into the Upper Three Runs Creek located $5.6 \mathrm{~km}(3.5 \mathrm{mi})$ to the southeast. There is no surface water connection between the MSSB and the drainage feature. Groundwater is approximately $46 \mathrm{~m}(150 \mathrm{ft})$ below land surface (bls) in the A Area and does not outcrop in the vicinity of the MSSB.

\section{OPERABLE UNIT HISTORY AND COMPLIANCE HISTORY}

\section{Operable Unit History}

The MSSB was constructed and placed in service in 1977 to receive liquid waste from the 716-A Motor Shops oil/water separator. The MSSB was designed and constructed as an unlined seepage basin. The basin measures $63.1 \mathrm{~m}(207.0 \mathrm{ft})$ long, $10.7 \mathrm{~m}(35.1 \mathrm{ft})$ wide, and $2.0 \mathrm{~m}(6.6 \mathrm{ft})$ deep (Huber et al. 1987). It is surrounded by a berm $2.0 \mathrm{~m}(6.6 \mathrm{ft})$ high. The wastewater flowed into the basin from the northwest through two influent pipes from the Motor Shop (Building 716-A) and seeped naturally into the soil beneath the basin. The basin has not been closed or capped, but all discharges to the basin were terminated in 1983 when the influent lines from the Motor Shops were capped (Huber et al. 1987). Effluent discharges from the Motor Shops included wastewater with trace amounts of engine oil, grease, kerosene, ethylene glycol, and soapy water. A ramp was built into the eastern end of the basin in 1988 (WSRC 1990) to facilitate soil sampling. At present, the basin collects rainwater during periods of heavy precipitation.

\section{Compliance History}

At SRS, waste materials regulated under the Resource Conservation and Recovery Act (RCRA) are managed in accordance with the requirements of RCRA. Certain SRS activities have required treatment, storage, disposal or post-closure permits under RCRA. Non-regulated units, called solid waste management units (SWMU), include any activity where hazardous constituents may remain uncontrolled and may potentially release to the environment. Investigation and potential corrective action for these SWMU(s) are mandated under RCRA 3004(u). On September 5, 1995, SRS received a hazardous waste permit from the South Carolina Department of Health and Environmental Control (SCDHEC) which includes corrective action requirements. Module IV of the permit specifies the corrective action requirements mandated by Section $3004(u)$ of RCRA.

Hazardous substances, as defined by CERCLA, are also present in the environment at the SRS. On December 21, 1989, SRS was included on the National Priorities List. This inclusion created a need to integrate the 
Figure 1. Location of MSSB at the Savannah River Site

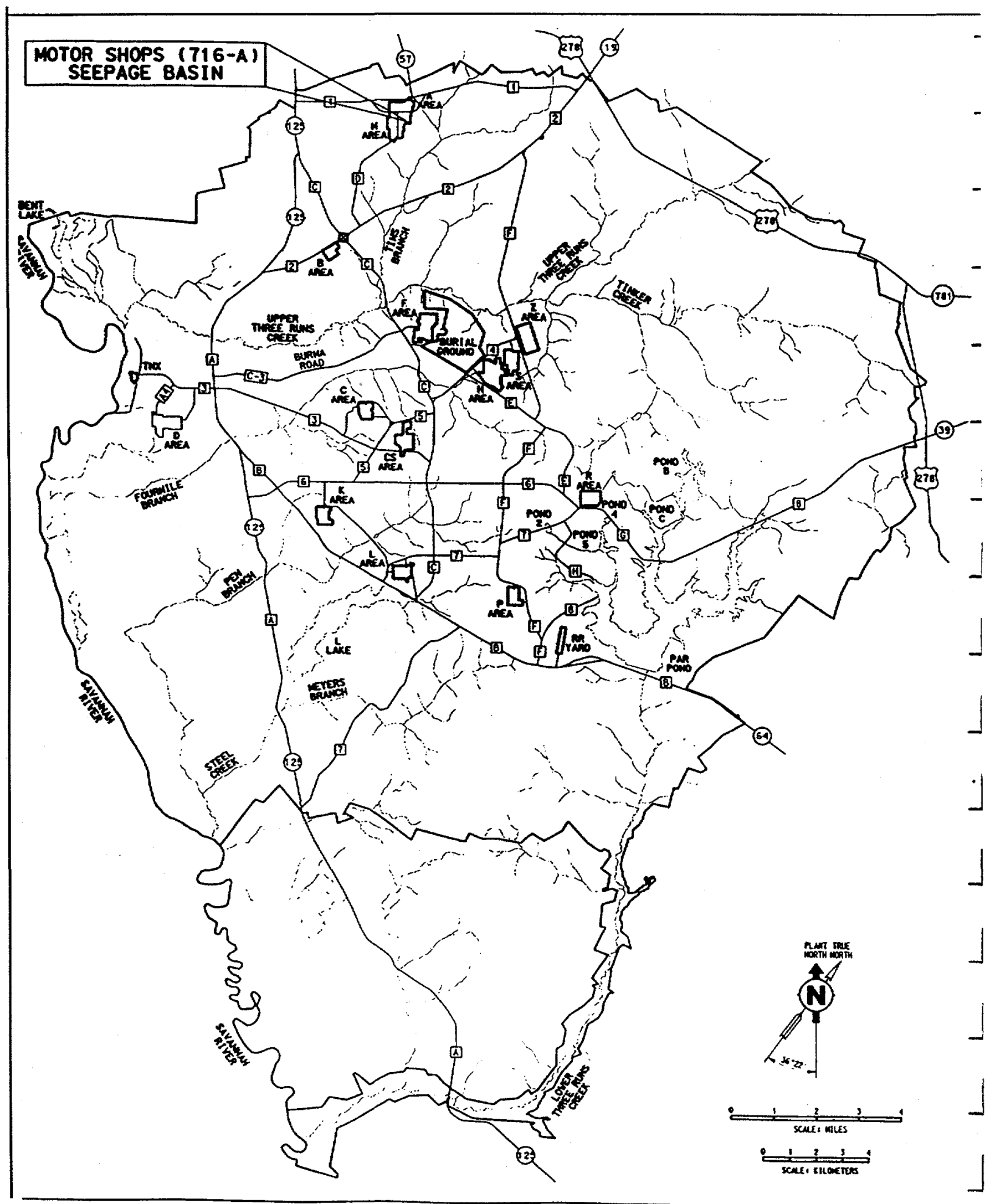



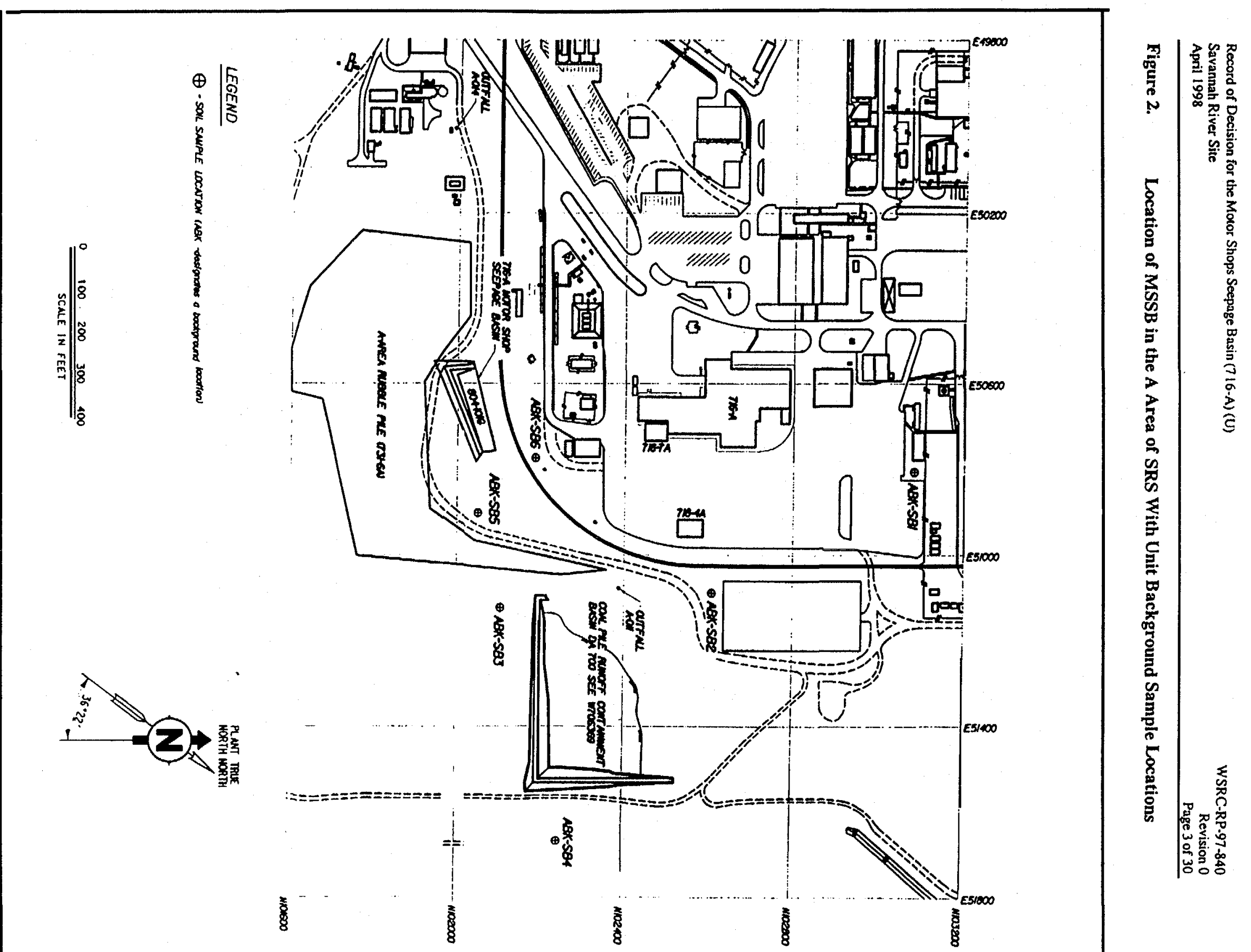
established RFI Program with CERCLA requirements to provide for a focused environmental program. In accordance with Section 120 of CERCLA, DOE has negotiated a Federal Facility Agreement (FFA 1993) with U. S. Environmental Protection Agency (EPA) and SCDHEC to coordinate remedial activities at SRS into one comprehensive strategy which fulfills these dual regulatory requirements.

The RCRA Facility Investigation/Remedial Investigation Work Plan for the 716-A Motor Shops Seepage Basin (WSRC 1996) was submitted to the regulators in 1996. The RCRA Facility Investigation/Remedial Investigation with the Baseline Risk Assessment for the 716-A Motor Shops Seepage Basin (WSRC 1997a) was submitted in accordance with the FFA and the approved implementation schedule, and approved by the EPA and the SCDHEC in September of 1997. The results of the investigation indicate that there is no impact (or potential impact) to human health or the environment from the MSSB. Therefore, No Action is warranted. No other alternatives were considered as indicated in the Statement of Basis/Proposed Plan for the Motor Shops Seepage Basin (716-A) (WSRC 1997b) which was approved by the regulators in January of 1998.

According to EPA guidance, if there is no current or potential threat to human health and the environment and No Action is warranted, the CERCLA 121 requirements are not triggered. This means that there is no need to evaluate other alternatives or the No Action alternative against the nine criteria specified under CERCLA.

The remedy selected satisfies both the CERCLA and RCRA 3004(u) requirements. The SCDHEC has modified the SRS RCRA permit to incorporate the No Action remedy.

\section{HIGHLIGHTS OF COMMUNITY PARTICIPATION}

Both RCRA and CERCLA require that the public be given an opportunity to review and comment on the draft permit modification and proposed remedial alternative. Public participation requirements are listed in South Carolina Hazardous Waste Management Regulation (SCHWMR) R.61-79.124 and Sections 113 and 117 of CERCLA. These requirements include establishment of an Administrative Record File that documents the investigation and selection of the remedial alternatives for addressing the MSSB soils and groundwater. The Administrative Record File must be established at or near the facility at issue. The SRS Public Involvement Plan (DOE 1994) is designed to facilitate public involvement in the decision-making process for permitting, closure, and the selection of remedial alternatives. The SRS Public Involvement Plan addresses requirements of RCRA, CERCLA, and the National Environmental Policy Act. SCHWMR R.61-79.124 and Section 117(a) of CERCLA, as amended, require the advertisement of the draft permit modification and notice of any proposed remedial action and provide the public an opportunity to participate in the selection of the remedial action. The Statement of Basis/Proposed Plan for the Motor Shops Seepage Basin (716-A) 1997b), which is part of the Administrative Record File, highlights key aspects of the investigation and identifies the preferred action for addressing the MSSB.

The FFA Administrative Record File, which contains the information pertaining to the selection of the response action, is available at the EPA office and at the following locations:

U.S. Department of Energy

Public Reading Room

Gregg-Graniteville Library

University of South Carolina-Aiken

171 University Parkway

Aiken, South Carolina 29801

(803) 641-3465
Thomas Cooper Library

Government Documents Department

University of South Carolina

Columbia, South Carolina 29208

(803) 777-4866

the 
Reese Library

Augusta State University

2500 Walton Way

Augusta, Georgia 30910

(706) $737-1744$
Asa H. Gordon Library

Savannah State University

Tompkins Road

Savannah, Georgia 31404

(912) 356-2183

The public was notified of the public comment period through mailings of the SRS Environmental Bulletin, a newsletter sent to approximately 3500 citizens in South Carolina and Georgia, through notices in the Aiken Standard, the Allendale Citizen Leader, the Augusta Chronicle, the Barnwell People-Sentinel, and The State newspapers. The public comment period was also announced on local radio stations.

The 45-day public comment period began on February 12, 1998 and ended on March 28, 1998. A Responsiveness Summary was prepared to address comments received during the public comment period. The Responsiveness Summary is provided in Appendix A of this Record of Decision. The public comment period for the RCRA Permit Modification began on February 12, 1998 and ended on March 28, 1998.

\section{SCOPE AND ROLE OF OPERABLE UNIT WITHIN THE SITE STRATEGY}

The overall strategy for addressing the MSSB was to: (1) characterize the waste unit delineating the nature and extent of contamination and identifying the media of concern (perform the RFI/RI); (2) perform a baseline risk assessment to evaluate media of concern, constituents of concern, exposure pathways, and characterize potential risks; and (3) evaluate and perform a final action to remediate, as needed, the identified media of concern.

The MSSB is an operable unit which is included in the Upper Three Runs watershed (Figure 3). The ground surface in the vicinity of the unit slopes gently to the southeast in the direction of Tims Branch. Tims Branch, the closest natural surface water drainage, is located approximately $1220 \mathrm{~m}(4000 \mathrm{ft})$ from the unit. There is no surface water connection between the MS SB and Tims Branch or any drainage feature in the area. Groundwater does not outcrop in the vicinity of the MSSB.

No action, which is the preferred remedy, is the final action. 
Figure 3. Upper Three Runs Watershed Area

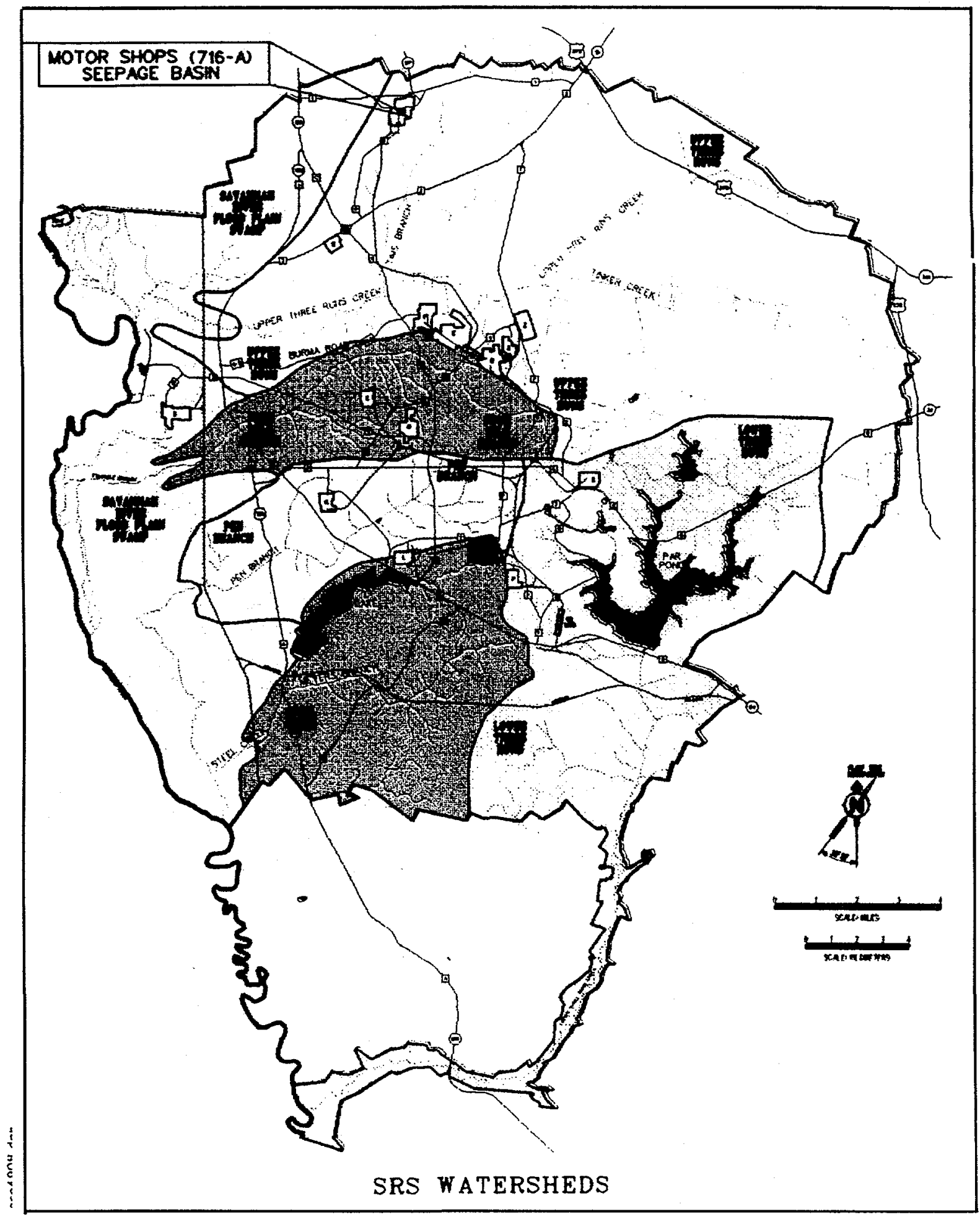




\section{SUMMARY OF OPERABLE UNIT CHARACTERISTICS}

For the analysis of the nature and extent of contamination, sample results are presented per the Conceptual Site Model (source and pathways), as well as by depth intervals comparable to those used in the Baseline Risk Assessment (see Figure 4). The original primary source of contamination was the wastewater discharges which ceased in 1983. All MSSB Phase I soil samples were used to characterize secondary sources of contamination (surface and subsurface soils). Depth intervals for presenting soil sample results were $0-0.3 \mathrm{~m}$ $(0-1 \mathrm{ft})$ and $0-1.2 \mathrm{~m}(0-4 \mathrm{ft})$ below land surface $(\mathrm{bls})$. The 0-1.2 $\mathrm{m}(0-4 \mathrm{ft})$ depth interval includes both the 0 $0.3 \mathrm{~m}(0-1 \mathrm{ft})$ and $0.3-1.2 \mathrm{~m}(1-4 \mathrm{ft})$ sample intervals.

Analytical results for MSSB Phase I soil samples were first screened against EPA risk-based concentrations (RBCs) or risk-based activities (RBAs) and then against unit-specific background levels. Constituents with detections exceeding both screening criteria were identified as Unit Specific Constituents (USCs). The only USC identified for the MSSB is benzo(a)pyrene, which was detected in one of 12 soil samples at a concentration exceeding both its RBC and twice average background level.

The Conceptual Site Model identifies soil, groundwater, air, and biota as possible exposure pathways for contamination from the MSSB. Groundwater was not sampled during the Phase I investigation. Groundwater sampling was to be performed during Phase II; however, since only one USC was detected (out of six on-unit soil sample locations) (See Figure 5) in Phase I unit soil samples, the Phase II investigation was deemed unwarranted. The decision rules presented in the work plan for the MSSB (WSRC 1996) supported terminating the investigation if no subsurface contamination from the basin was found during Phase I. Area groundwater is under evaluation as part of the overall groundwater remediation approach as presented in the RCRA permit application Corrective Action Plan for the A-014 outfall area (Volume III, M-Area HWMF, WSRC-IM-91-53). Biota and air also were not sampled during the Phase I investigation. Potential contaminant concentrations in biota and air are derived during the Baseline Risk Assessment based on constituent levels measured in surface and subsurface soils.

The soils along the process sewer line were also to be characterized during the Phase II investigation if warranted by Phase I results. The Phase I soil results represent the worst case scenario for the MSSB. Based on the low levels of contamination detected and the identification of only one USC, soil sampling along the process sewer line was also deemed unwarranted. 
Record of Decision for the Motor Shops Seepage Basin (716-A) (U)

Figure 4. Conceptual Site Model for the Motor Shops Seepage Basin

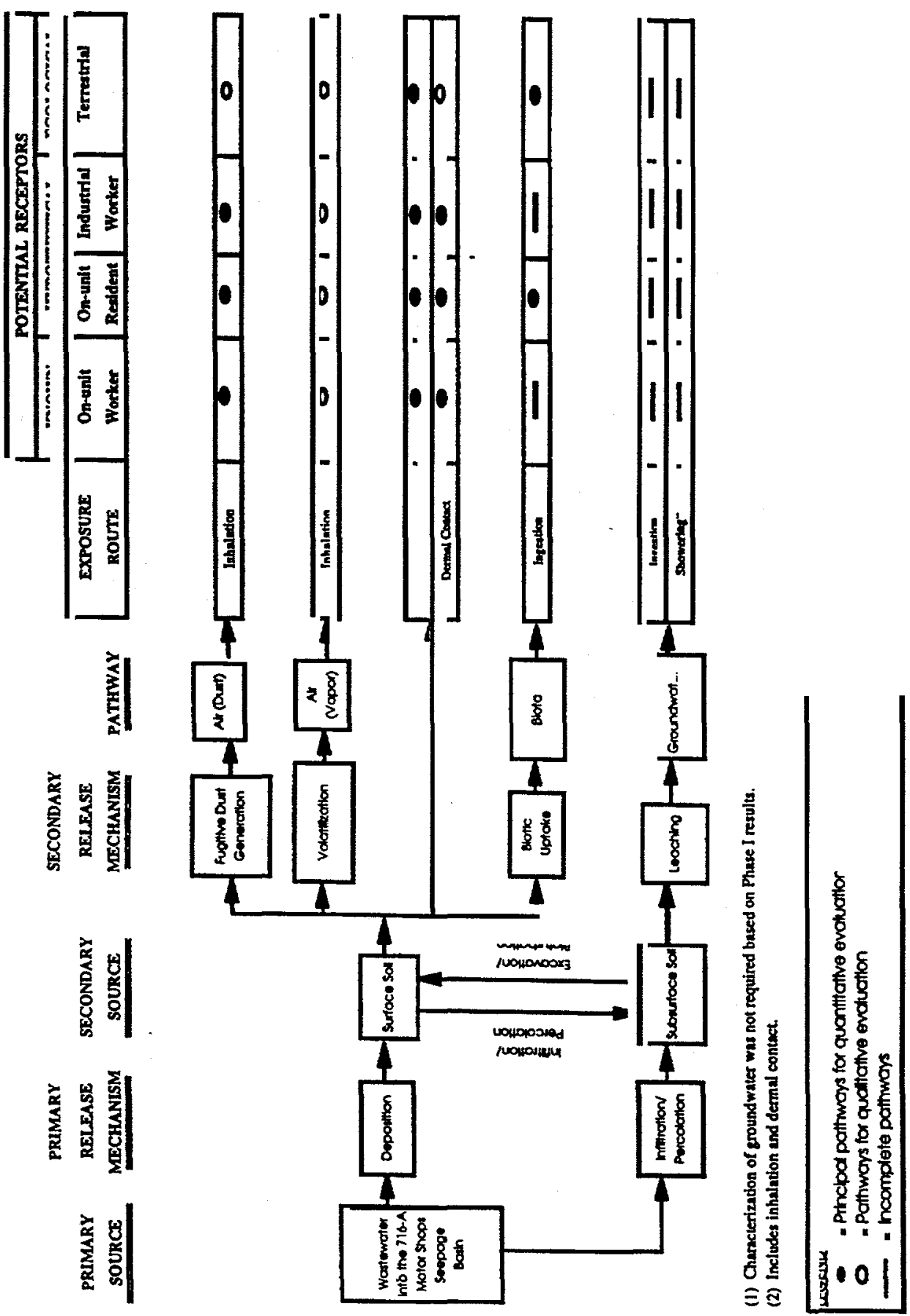




\section{Media Assessment}

Hand-augered soil borings were made at locations ABK-SB 1 through ABK-SB6 (Figure 2) during the Phase I investigation to establish background conditions for unit soils. These locations are topographically and hydraulically upgradient from the MSSB. The samples were collected from Udorthent soils at sample depths corresponding to the depth of samples collected from the basin. Two soil samples were collected at each location at depth intervals of 0-0.3 m (0-1 ft) and 0.3-1.2 $\mathrm{m}(1-4 \mathrm{ft})$ bls. Background soil sample locations were carefully selected and are spread out over a large area due to the presence of existing buildings, roads, and other facilities (Figure 2). The sampling locations were in areas considered to be unaffected by potential contamination from the MSSB.

Within the basin, hand-augured soil borings were advanced at six locations, AOB-SB 1 through AOB-SB6 (Figure 5), during the Phase I investigation. Two soil samples were collected at each location at depth intervals of $0-0.3 \mathrm{~m}(0-1 \mathrm{ft})$ and $0.3-1.2 \mathrm{~m}(1-4 \mathrm{ft})$ bls.

Table 1 presents the background data summary for constituents detected in surface soil $(0-0.3 \mathrm{~m}[0-1 \mathrm{ft}]$ bls $)$ samples. Background values are calculated by averaging the constituent concentrations detected in all six surface soil samples. If an analyte was not detected in background surface soil samples but was detected in unit surface soil samples, a value of one-half the MDL is substituted for the analyte concentration for calculating the average background value. The twice average concentration levels presented in this table are then compared to detections in unit surface soil samples as a screening level (Table 2).

Table 3 presents the background data summary for constituents detected in subsurface soil $(0-1.2 \mathrm{~m}[0-4 \mathrm{ft}]$ bls) samples. Background values for subsurface soils are calculated similarly to surface soils, except that all 12 samples are used (i.e., six samples from 0-0.3 $\mathrm{m}$ [0-1 ft] and six samples from 0.3-1.2 $\mathrm{m}$ [1-4 f] bls). The twice average concentration levels presented in this table are then used for comparisons to unit subsurface soil sample detections (Table 4).

Deep soils, process sewer line soils, and groundwater were to be sampled during the Phase II investigation, however, based on the Phase I (worst case) results, Phase II was not required. 
Record of Decision for the Motor Shops Seepage Basin (716-A) (U)

Savannah River Site

WSRC-RP-97-840

Revision 0

April 1998

Page 10 of 30

Table 1. Summary of Analytes Detected in Background Surface (0-0.3 m [0-1 ft]) Soil Samples

\begin{tabular}{|c|c|c|c|c|c|c|}
\hline Analyte Class & Analyte & $\begin{array}{c}\text { Frequency of } \\
\text { Detection }\end{array}$ & Units & $\begin{array}{l}\text { Maximum } \\
\text { Detection }\end{array}$ & $\begin{array}{c}\text { Average } \\
\text { Detection }\end{array}$ & $\begin{array}{c}2 \mathrm{x} \text { Average } \\
\text { Detection }\end{array}$ \\
\hline \multirow[t]{4}{*}{ Volatiles } & 1,1,1-Trichloroethane & $5 / 5$ & $\mathrm{mg} / \mathrm{kg}$ & $1.13 \mathrm{E}-02$ & $6.62 \mathrm{E}-03$ & $1.32 \mathrm{E}-02$ \\
\hline & Tetrachloroethene & $5 / 5$ & $\mathrm{mg} / \mathrm{kg}$ & $1.30 \mathrm{E}-02$ & $1.04 \mathrm{E}-02$ & $2.07 E-02$ \\
\hline & \begin{tabular}{|l|} 
Toluene \\
\end{tabular} & $1 / 5$ & $\mathrm{mg} / \mathrm{kg}$ & $2.23 \mathrm{E}-03$ & 1.03E-03 & 2.05E-03 \\
\hline & Xylenes (total) & 215 & $\mathrm{mg} / \mathrm{kg}$ & $3.50 \mathrm{E}-03$ & $1.40 \mathrm{E}-03$ & $2.81 E-03$ \\
\hline \multirow[t]{11}{*}{ Semivolatiles } & Anthracene & $1 / 6$ & $\mathrm{mg} / \mathrm{kg}$ & $3.68 \mathrm{E}-02$ & $1.28 \mathrm{E}-02$ & $2.56 \mathrm{E}-02$ \\
\hline & Benzo(a)anthracene & $2 / 6$ & $\mathrm{mg} / \mathrm{kg}$ & $1.1 / 2 E \Gamma^{2}$ & $3.45 \mathrm{E}-02$ & $6.91 \mathrm{E}-02$ \\
\hline & Benzo(a)pyrene & $2 / 6$ & $\mathrm{mg} / \mathrm{kg}$ & $1.1 .3 \mathrm{E}-21.1$ & $356 F_{2} 03-1$ & $7.1 .1 \mathrm{E}-02$ \\
\hline & Benzo(b)fluoranthene & $2 / 6$ & $\mathrm{mg} / \mathrm{kg}$ & $1.04 \mathrm{E}-01$ & $3.46 \mathrm{E}-02$ & $6.91 \mathrm{E}-02$ \\
\hline & Benzo(g,h,i)perylene & $1 / 6$ & $\mathrm{mg} / \mathrm{kg}$ & $6.98 \mathrm{E}-02$ & $1.83 \mathrm{E}-02$ & $3.66 \mathrm{E}-02$ \\
\hline & Benzo(k)fluoranthene & $2 / 6$ & $\mathrm{mg} / \mathrm{kg}$ & $1.08 \mathrm{E}-01$ & $3.74 \mathrm{E}-02$ & $7.48 \mathrm{E}-02$ \\
\hline & Chrysene & $2 / 6$ & $\mathrm{mg} / \mathrm{kg}$ & $1.58 \mathrm{E}-01$ & $4.64 \mathrm{E}-02$ & 9.27E-02 \\
\hline & Fluoranthene & $2 / 6$ & $\mathrm{mg} / \mathrm{kg}$ & $2.49 \mathrm{E}-01$ & $6.70 \mathrm{E}-02$ & $1.34 \mathrm{E}-01$ \\
\hline & $\begin{array}{l}\text { Indeno(1,2,3- } \\
\text { c.d)nvrene }\end{array}$ & $1 / 6$ & $\mathrm{mg} / \mathrm{kg}$ & $6.61 \mathrm{E}-02$ & $1.85 \mathrm{E}-02$ & $3.70 \mathrm{E}-02$ \\
\hline & Phenanthrene & $1 / 6$ & $\mathrm{mg} / \mathrm{kg}$ & $1.72 \mathrm{E}-01$ & $3.49 \mathrm{E}-02$ & $6.98 \mathrm{E}-02$ \\
\hline & Pyrene & $2 / 6$ & $\mathrm{mg} / \mathrm{kg}$ & $2.04 \mathrm{E}-01$ & $5.85 \mathrm{E}-02$ & $1.17 \mathrm{E}-01$ \\
\hline \multirow[t]{2}{*}{ Pesticides/PCBs } & p,p'-DDE & $1 / 6$ & $\mathrm{mg} / \mathrm{kg}$ & $5.88 \mathrm{E}-03$ & $1.36 \mathrm{E}-03$ & $2.71 \mathrm{E}-03$ \\
\hline & p,p'-DDT & $1 / 6$ & $\mathrm{mg} / \mathrm{kg}$ & $4.78 \mathrm{E}-03$ & $1.26 \mathrm{E}-03$ & $2.51 \mathrm{E}-03$ \\
\hline \multirow[t]{15}{*}{ TAL Inorganics } & Aluminum & $6 / 6$ & $\mathrm{mg} / \mathrm{kg}$ & $9.99 \mathrm{E}+03$ & $5.78 \mathrm{E}+03$ & $1.16 \mathrm{E}+04$ \\
\hline & Antimony & $2 / 6$ & $\mathrm{mg} / \mathrm{kg}$ & $7.245-01$ & $33.47 E-01$ & $6.94 \mathrm{E}-01$ \\
\hline & Arsenic & $4 / 6$ & $\mathrm{mg} / \mathrm{kg}$ & $5.00 \mathrm{E}+00$ & $2.25 E+00$ & $4.50 \mathrm{E}+00$ \\
\hline & Barium & $6 / 6$ & $\mathrm{mg} / \mathrm{kg}$ & $2.47 \mathrm{E}+01$ & $1.76 \mathrm{E}+01$ & $3.52 \mathrm{E}+01$ \\
\hline & Beryllium & $5 / 6$ & $\mathrm{mg} / \mathrm{kg}$ & $2.74 \mathrm{E}-01$ & $1.63 \mathrm{E}-01$ & $3.26 \mathrm{E}-01$ \\
\hline & Cadmium & $6 / 6$ & $\mathrm{mg} / \mathrm{kg}$ & $9.72 \mathrm{E}-01$ & $3.27 \mathrm{E}-01$ & $6.55 \mathrm{E}-01$ \\
\hline & Calcium & $6 / 6$ & $\mathrm{mg} / \mathrm{kg}$ & $2.81 E+03$ & $6.37 \mathrm{E}+02$ & $1.27 E+03$ \\
\hline & Chromium & $6 / 6$ & $\mathrm{mg} / \mathrm{kg}$ & $2.55 \mathrm{E}+01$ & $1.04 \mathrm{E}+01$ & $2.09 E+01$ \\
\hline & Cobalt & $6 / 6$ & $\mathrm{mg} / \mathrm{kg}$ & $1.30 \mathrm{E}+00$ & $9.69 \mathrm{E}-01$ & $1.94 \mathrm{E}+00$ \\
\hline & Copper & $6 / 6$ & $\mathrm{mg} / \mathrm{kg}$ & $4.00 \mathrm{E}+00$ & $2.42 \mathrm{E}+00$ & $4.83 \mathrm{E}+00$ \\
\hline & Iron & $6 / 6$ & $\mathrm{mg} / \mathrm{kg}$ & $2.07 \mathrm{E}+04$ & $7.87 \mathrm{E}+03$ & $1.57 \mathrm{E}+04$ \\
\hline & Lead & $6 / 6$ & $\mathrm{mg} / \mathrm{kg}$ & $1.30 \mathrm{E}+01$ & $6.72 \mathrm{E}+00$ & $1.34 \mathrm{E}+01$ \\
\hline & Sodium & $5 / 6$ & $\mathrm{mg} / \mathrm{kg}$ & $3.95 \mathrm{E}+01$ & $2.01 \mathrm{E}+01$ & $4.02 E+01$ \\
\hline & Vanadium & $6 / 6$ & $\mathrm{mg} / \mathrm{kg}$ & $5.01 \mathrm{E}+01$ & $1.99 \mathrm{E}+01$ & $3.98 \mathrm{E}+01$ \\
\hline & Zinc & $6 / 6$ & $\mathrm{mg} / \mathrm{kg}$ & $3.09 \mathrm{E}+01$ & $1.22 \mathrm{E}+01$ & $2.44 \mathrm{E}+01$ \\
\hline Radiological & Gross Alpha & $5 / 6$ & $\mathrm{pCi} / \mathrm{g}$ & $2.72 \mathrm{E}+01$ & $1.27 \mathrm{E}+01$ & $2.54 \mathrm{E}+01$ \\
\hline Indicators & Nonyolatile Beta & $3 / 6$ & $\mathrm{pCi} / \mathrm{g}$ & $1.85 \mathrm{E}+01$ & $1.00 \mathrm{E}+01$ & $2.01 E+01$ \\
\hline Miscellaneous & $\begin{array}{l}\text { Total petroleum } \\
\text { hydrocarbons }\end{array}$ & $4 / 6$ & $\mathrm{mg} / \mathrm{kg}$ & $7.56 \mathrm{E}+01$ & $2.34 \mathrm{E}+01$ & $4.69 E+01$ \\
\hline
\end{tabular}


Table 2.

Summary of Analytes Detected in 716-A Motor Shops Seepage Basin Surface $(0-0.3 \mathrm{~m}$ [0-1 ft]) Soils

\begin{tabular}{|c|c|c|c|c|c|c|c|c|}
\hline Analyte Class & Andyte & $\begin{array}{c}\text { Frequency of } \\
\text { Detection }\end{array}$ & Units & $\begin{array}{l}\text { Masinsem } \\
\text { Detection }\end{array}$ & $\begin{array}{l}\text { Areras: } \\
\text { Detection }\end{array}$ & $\mathbf{R B C} \mathbf{C}^{2}$ & $\begin{array}{l}2 x \text { A rerage } \\
\text { Background }\end{array}$ & $\begin{array}{l}\text { Retrined os } \\
\mathrm{USC}^{3}(\mathrm{YNN})\end{array}$ \\
\hline \multirow[t]{2}{*}{ Volntiles } & 1,1,1-Trichloroethane & $4 / 5$ & $\mathrm{mg} / \mathrm{kg}$ & $1.03 E-02$ & $5.16 \mathrm{E}-03$ & $2.70 \mathrm{E}+02$ & 1.32E-02 & $N$ \\
\hline & Tetrachloroethene & $5 / 5$ & $\mathrm{mg} / \mathrm{kg}$ & $1.31 \mathrm{E}-02$ & $6.97 \mathrm{E}-03$ & $1.20 \mathrm{E}+01$ & $2.07 \mathrm{E}-02$ & $\mathbf{N}$ \\
\hline \multirow[t]{14}{*}{ Semivolatiles } & Acenaphthene & $1 / 6$ & $\mathrm{mg} / \mathrm{kg}$ & $1.00 \mathrm{E}-01$ & $2.29 \mathrm{E}-02$ & $4.70 \mathrm{E}+02$ & $1.50 \mathrm{E}-02$ & $\mathbf{N}$ \\
\hline & Anthracene & $1 / 6$ & $\mathrm{mg} / \mathrm{kg}$ & $2.30 \mathrm{E}-01$ & $4.50 \mathrm{E}-02$ & $2.30 \mathrm{E}+03$ & $2.56 \mathrm{E}-02$ & $N$ \\
\hline & Benzo(a)anthracene & $1 / 6$ & $\mathrm{mg} / \mathrm{kg}$ & $5.03 E-01$ & $9.22 \mathrm{E}-02$ & 8.80E-01 & $6.91 \mathrm{E}-02$ & $N$ \\
\hline & Benzo(a)pyrene & $1 / 6$ & $\mathrm{mg} / \mathrm{kg}$ & 4.10E-01 & $7.83 \mathrm{E}-02$ & $8.80 \mathrm{E}-02$ & $7.11 \mathrm{E}-02$ & $Y$ \\
\hline & Benzo(b)fluoranthene & $2 / 6$ & $\mathrm{mg} / \mathrm{kg}$ & 4.10E-01 & 8.70E-02 & 8.80E-01 & $6.91 \mathrm{E}-02$ & $\mathbf{N}$ \\
\hline & Benzo $(g, h, i)$ perylene ${ }^{4}$ & 116 & $\mathrm{mg} / \mathrm{kg}$ & $2.67 \mathrm{E}-01$ & $5.12 \mathrm{E}-02$ & $2.30 \mathrm{E}+02$ & $3.66 \mathrm{E}-02$ & $\mathbf{N}$ \\
\hline & Benzo(k)fluoranthene & 216 & $m q^{2}=$ & $3.66 \mathrm{E}-01$ & 7.57E-02 & $8.80 \mathrm{E}+00$ & $7.48 \mathrm{E}-02$ & $\mathbf{N}$ \\
\hline & Chrysene & 216 & $\mathrm{mg} / \mathrm{kg}$ & $5.34 \mathrm{E}-01$ & $1.05 \mathrm{E}-01$ & $8.80 \mathrm{E}+01$ & 9.27E-02 & $\mathbf{N}$ \\
\hline & Dbenzofuran & $1 / 6$ & $\mathrm{mg} / \mathrm{kg}$ & 5.98E-02 & $1.66 \mathrm{E}-02$ & $3.10 E+01$ & $1.60 \mathrm{E}-02$ & $\mathbf{N}$ \\
\hline & Fluoranthene & $2 / 6$ & mêks & $1.10 E+\infty 0$ & $1.98 \mathrm{E}-01$ & $3.10 \mathrm{E}+02$ & $1.34 \mathrm{E}-01$ & $\mathbf{N}$ \\
\hline & Fluorene & 116 & $\mathrm{mg} / \mathrm{kg}$ & $1.02 E-01$ & $2.37 \mathrm{E}-02$ & $3.10 \mathrm{E}+02$ & $1.60 \mathrm{E}-02$ & $\mathbf{N}$ \\
\hline & Indeno( $1,2,3-c, d)$ pyrene & $1 / 6$ & $\mathrm{mg} / \mathrm{kg}$ & $2.22 \mathrm{E}-01$ & $4.45 \mathrm{E}-02$ & 8.80E-0I & $3.70 \mathrm{E}-02$ & $\mathbf{N}$ \\
\hline & Phenanthrene ${ }^{3}$ & 116 & $\mathrm{mg} / \mathrm{kg}$ & $9.48 \mathrm{E}-01$ & $1.64 \mathrm{E}-01$ & $3.10 \mathrm{E}+02$ & $6.98 \mathrm{E}-02$ & $\mathbf{N}$ \\
\hline & Pyrene & $2 / 6$ & $\mathrm{mg} / \mathrm{kg}$ & $8.95 \bar{E}-01$ & $.63 \mathrm{E}-01$ & $2.30 \mathrm{E}+02$ & $1.17 \mathrm{E}-01$ & $\mathbf{N}$ \\
\hline Pesticides/PCBs & Aroclor $1260^{\circ}$ & $2 / 6$ & $\mathrm{mg} / \mathrm{kg}$ & $6.76 \mathrm{E}-02$ & $2.39 \mathrm{E}-02$ & $8.30 \mathrm{E}-02$ & $1.10 \mathrm{E}-02$ & $\mathbf{N}$ \\
\hline \multirow{20}{*}{ TAL Inorganies } & Aluminum & $6 / 6$ & $\mathrm{mg} / \mathrm{kg}$ & $4.27 E+03$ & 3.64E+03 & $7.80 \mathrm{E}+03$ & $1.16 \mathrm{E}+04$ & $\mathbf{N}$ \\
\hline & Arsenic & 216 & $\mathrm{mg} / \mathrm{kg}$ & $1.70 \mathrm{E}+00$ & $8.87 \mathrm{E}-0.1$ & 4.30E-01 & $4.50 \mathrm{E}+00$ & $N$ \\
\hline & Barium & 616 & $\mathrm{mg} / \mathrm{kg}$ & $3.49 E+01$ & $1.84 E+01$ & $5.50 \mathrm{E}+02$ & $3.52 \mathrm{E}+01$ & $\mathbf{N}$ \\
\hline & Beryllium & $4 / 6$ & $\mathrm{mg} / \mathrm{kg}$ & $2.30 \mathrm{E}-01$ & $9.28 \mathrm{E}-02$ & $1.50 \mathrm{E}-01$ & $3.26 \mathrm{E}-01$ & $\mathbf{N}$ \\
\hline & Cadmium & $6 / 6$ & $\mathrm{mg} / \mathrm{kg}$ & $1.50 E+00$ & $4.69 \mathrm{E}-01$ & $3.90 \mathrm{E}+00$ & $6.55 \mathrm{E}-01$ & $N$ \\
\hline & Calcium & $6 / 6$ & $\mathbf{m g} / \mathbf{k g}$ & $2.71 \mathrm{E}+02$ & $1.09 \mathrm{E}+02$ & $\mathrm{EN}^{\top}$ & $1.27 E+03$ & $\mathbf{N}$ \\
\hline & Chromium & $6 / 6$ & $\mathrm{mg} / \mathrm{kg}$ & $7.20 \mathrm{E}+00$ & $4.97 \mathrm{E}+00$ & $3.90 \mathrm{E}+01$ & $2.09 \mathrm{E}+01$ & $\mathbf{N}$ \\
\hline & Cobalt & $6 / 6$ & $\mathrm{mg} / \mathrm{kg}$ & $7.34{ }_{2}-\mathrm{O}_{2}$ & S. $58 E-01$ & $4.70 \mathrm{E}+02$ & $1.94 \mathrm{E}+00$ & $N$ \\
\hline & Copper & $6 / 6$ & $\mathrm{mg} / \mathrm{kg}$ & $1.21 E+01$ & $5.08 \mathrm{E}+00$ & $3.10 \mathrm{E}+02$ & $4.83 E+00$ & $\mathbf{N}$ \\
\hline & Cyanide & $1 / 6$ & $\mathrm{mg} / \mathrm{kg}$ & $2.705-01$ & $7.83 \mathrm{E}-02$ & $1.60 \mathrm{E}+02$ & $8.00 \mathrm{E}-02$ & $\mathbf{N}$ \\
\hline & Iron & $6 / 6$ & $\mathrm{mg} / \mathrm{kg}$ & $3.50 \mathrm{E}+03$ & $2.17 \mathrm{E}+03$ & $2.30 \mathrm{E}+03$ & $1.57 \mathrm{E}+04$ & $\mathbf{N}$ \\
\hline & Lead & 616 & $\mathrm{mg} / \mathrm{kg}$ & $1.30 \mathrm{E}+01$ & $7.80 \mathrm{E}+00$ & $4.00 \mathrm{E}+02$ & $1.34 \mathrm{E}+01$ & $\mathbf{N}$ \\
\hline & Magnesium & $6 / 6$ & $\mathrm{mg} / \mathrm{kg}$ & $1.15 E+02$ & $7.31 \mathrm{E}+01$ & EN & $3.09 \mathrm{E}+02$ & $\mathbf{N}$ \\
\hline & Manganese & 616 & meskg & $6.99 \mathrm{E}+01$ & $2.54 \mathrm{E}+01$ & $1.80 \mathrm{E}+02$ & $2.36 \mathrm{E}+02$ & $\mathbf{N}$ \\
\hline & Mercury & 616 & $\mathrm{mg} / \mathrm{kg}$ & $5.60 \mathrm{E}-02$ & $2.77 \mathrm{E}-02$ & $2.30 \mathrm{E}+00$ & $4.18 \mathrm{E}-02$ & $\mathbf{N}$ \\
\hline & Nickel & $6 / 6$ & $\mathrm{mg} / \mathrm{kg}$ & $2.40 \mathrm{E}+00$ & $1.65 E+00$ & $1.60 \mathrm{E}+02$ & $3.57 \mathrm{E}+00$ & $\mathbf{N}$ \\
\hline & Potassium & $6 / 6$ & $\mathrm{mg} / \mathrm{kg}$ & $1.4 ! \mathrm{E}+02$ & $7.48 \mathrm{E}+01$ & $\mathbf{E N}$ & $1.77 \mathrm{E}+02$ & $\mathbf{N}$ \\
\hline & Sodium & 416 & $\mathrm{mg} / \mathrm{kg}$ & $2.43 \mathrm{E}+01$ & $1.57 \mathrm{E}+01$ & EN & $4.02 \mathrm{E}+01$ & $\mathbf{N}$ \\
\hline & Vanadium & $6 / 6$ & $\mathrm{mg} / \mathrm{kg}$ & $8.10 \mathrm{E}+00$ & $5.98 \mathrm{E}+00$ & $5.50 \mathrm{E}+01$ & $3.98 \mathrm{E}+01$ & $N$ \\
\hline & Zinc & 616 & $\mathrm{mg} / \mathrm{kg}$ & $6.46 \mathrm{E}+01$ & $1.94 \mathrm{E}+01$ & $2.30 \mathrm{E}+03$ & $2.44 E+01$ & $N$ \\
\hline \multirow[t]{2}{*}{$\begin{array}{l}\text { Radiological } \\
\text { Indicators } \\
\end{array}$} & Gross Alpha & $3 / 6$ & $\mathrm{pCV} / \mathrm{g}$ & $1.46 \mathrm{E}+01$ & $6.75 E+00$ & $\mathrm{NR}^{8}$ & $2.54 E+01$ & $N$ \\
\hline & Nonvolatile Beta & $3 / 6$ & $\mathrm{pCV} g$ & $1.59 \mathrm{E}+01$ & $8.81 \mathrm{E}+00$ & NR & $2.01 \mathrm{E}+01$ & $\mathbf{N}$ \\
\hline Miscellaneous & $\begin{array}{l}\text { Total petroleum } \\
\text { hydrocarbons }\end{array}$ & $5 / 6$ & $\mathrm{mg} / \mathrm{kg}$ & $5.30 \mathrm{E}+02$ & $1.81 \mathrm{E}+02$ & $N^{\prime}{ }^{9}$ & $4.69 \mathrm{E}+01$ & $\mathbf{N}$ \\
\hline
\end{tabular}

Notes

1) A value equal to $2 X$ the average background.

Analytes not detected in background samples are shown in bold ifalics.

2) (2) Risk Based Concentrations for residential soil ane from EPA Region III, April 19\%. Values for radiological indicators are from Nix (1996).

Value for total recoverable lead is EPA Region IV action limit.

(b) A value of zero is used for essential nutrienis and analytes with no reported RBC.

3) USC for unit-specific constituen (exceeds twice average background).

4) RBC for Pyrene used as a surrogate value.

5) RBC for Fluorene used as a surrogate value.

6) RBC for Polychlorinated Biphenyl (PCB) used as surrogate value.

7) $\mathrm{EN}=$ Essential nutrient

8) $N R=$ Not reported

9) NA $=$ Not applicabie 
Table 3. Summary of Analytes Detected in Background Subsurface (0-1.2 m [0-4 $\mathrm{ft}])$ Soil Samples

\begin{tabular}{|c|c|c|c|c|c|c|}
\hline Analyte & Anal te & $\begin{array}{c}\text { Frequency of } \\
\text { Detection }\end{array}$ & Units & $\begin{array}{l}\text { Maximum } \\
\text { Detection }\end{array}$ & $\begin{array}{l}\text { Average } \\
\text { Detection }\end{array}$ & $\begin{array}{l}\text { 2x Average } \\
\text { Detection }\end{array}$ \\
\hline \multirow[t]{4}{*}{ Yolatiles } & 1,1,1-Trichioroethane & $8 / 11$ & $\mathrm{mg} / \mathrm{kg}$ & $1.13 \mathrm{E}-02$ & 4.03E-03 & $8.06 \mathrm{E}-03$ \\
\hline & Tetrachloroethene & $11 / 11$ & $\mathrm{mg} / \mathrm{kg}$ & $1.30 \mathrm{E}-02$ & $7.10 \mathrm{E}-03$ & $1.42 \mathrm{E}-02$ \\
\hline & Toluene & 2111 & $\mathrm{mg} / \mathrm{kg}$ & $2.23 \mathrm{E}-03$ & $9.58 \mathrm{E}-04$ & $1.92 \mathrm{E}-03$ \\
\hline & Xylenes (total) & $3 / 11$ & $\mathrm{mg} / \mathrm{kg}$ & $3.50 \mathrm{E}-03$ & $1.25 \mathrm{E}-03$ & $2.49 \mathrm{E}-03$ \\
\hline \multirow[t]{11}{*}{ Semivolatiles } & Anthrucene & $1 / 12$ & $\mathrm{mg} / \mathrm{kg}$ & $3.68 \mathrm{E}-02$ & $1.04 \mathrm{E}-02$ & $2.08 \mathrm{E}-02$ \\
\hline & Benzo(a)anthracene & $2 / 12$ & $\mathrm{mg} / \mathrm{kg}$ & $1.17 \mathrm{E}-01$ & $2.23 \mathrm{E}-02$ & $4.45 \mathrm{E}-02$ \\
\hline & Benzo(a)pyrene & $2 / 12$ & $\mathrm{mg} / \mathrm{kg}$ & $1.13 \mathrm{E}-01$ & $2.38 \mathrm{E}-02$ & $4.36 \mathrm{E}-02$ \\
\hline & Benzo(b)fluoranthene & 2112 & $\mathrm{mg} / \mathrm{kg}$ & $1.04 \mathrm{E}-01$ & $2.30 \mathrm{E}-02$ & $4.61 \mathrm{E}-02$ \\
\hline & Benzo(g,h,i)perylene & $1 / 12$ & $\mathrm{mg} / \mathrm{kg}$ & $6.98 \mathrm{E}-02$ & $1.32 \mathrm{E}-02$ & $2.63 E-02$ \\
\hline & Benzo(k)fluoranthene & $2 / 12$ & $\mathrm{mg} / \mathrm{kg}$ & $1.08 \mathrm{E}-01$ & $2.42 \mathrm{E}-02$ & $4.84 \mathrm{E}-02$ \\
\hline & Chrysene & $2 / 12$ & $\mathrm{mg} / \mathrm{kg}$ & $1.58 \mathrm{E}-01$ & $2.79 \mathrm{E}-02$ & $5.59 \mathrm{E}-02$ \\
\hline & luoranthene & $2 / 12$ & $\mathrm{mg} / \mathrm{kg}$ & $2.49 \mathrm{E}-01$ & $3.83 \mathrm{E}-02$ & $7.65 \mathrm{E}-02$ \\
\hline & Indeno( $(1,2,3-c, d)$ pyrene & $1 / 12$ & $\mathrm{mg} / \mathrm{kg}$ & $6.6 \mathrm{IE}-02$ & $1.38 \mathrm{E}-02$ & $2.75 E-02$ \\
\hline & Phenanthrene & $1 / 12$ & $m g / k g$ & $1.72 \mathrm{E}-01$ & $2.12 E-02$ & $4.24 \mathrm{E}-02$ \\
\hline & Pyrene & $2 / 12$ & $\mathrm{mg} / \mathrm{kg}$ & $2.04 \mathrm{E}-01$ & $3.45 \mathrm{E}-02$ & $6.90 \mathrm{E}-02$ \\
\hline \multirow[t]{2}{*}{ Pesticides/PCBs } & p., -DDE & $1 / 12$ & $\mathrm{mg} / \mathrm{kg}$ & $5.88 \mathrm{E}-03$ & $9.03 \mathrm{E}-04$ & $1.81 \mathrm{E}-03$ \\
\hline & P,p'-DDT & $1 / 12$ & $\mathrm{mg} / \mathrm{kg}$ & $4.78 \mathrm{E}-03$ & $9.03 E-04$ & $1.81 \mathrm{E}-03$ \\
\hline \multirow[t]{20}{*}{ rAL Inorganics } & Aluminum & $12 / 12$ & $\mathrm{mg} / \mathrm{kg}$ & $1.02 \mathrm{E}+04$ & $7.87 \mathrm{E}+\mathrm{U} 3$ & $1.57 \mathrm{E}+04$ \\
\hline & Antimony & $5 / 12$ & $\mathrm{mg} / \mathrm{kg}$ & $9.49 \mathrm{E}-01$ & $3.74 \mathrm{E}-01$ & $7.48 \mathrm{E}-01$ \\
\hline & Arsenic & $9 / 12$ & $\mathrm{mg} / \mathrm{kg}$ & $5.90 \mathrm{E}+00$ & $2.56 \mathrm{E}+00$ & $5.13 \mathrm{E}+00$ \\
\hline & Barium & $12 / 12$ & $\mathrm{mg} / \mathrm{kg}$ & $4.39 \mathrm{E}+01$ & $2.17 \mathrm{E}+01$ & $4.25 E+01$ \\
\hline & Beryllium & $11 / 12$ & $\mathrm{mg} / \mathrm{kg}$ & $4.07 \mathrm{E}-01$ & $2.10 \mathrm{E}-01$ & $4.21 \mathrm{E}-01$ \\
\hline & Cadmium & $11 / 12$ & $\mathrm{mg} / \mathrm{kg}$ & $9.72 \mathrm{E}-01$ & $3.27 \mathrm{E}-01$ & $6.54 \mathrm{E}-01$ \\
\hline & Calcium & $12 / 12$ & $\mathrm{mg} / \mathrm{kg}$ & $2.81 E+03$ & $4.46 \mathrm{E}+02$ & $8.92 \mathrm{E}+02$ \\
\hline & Chromium & $12 / 12$ & $\mathrm{mg} / \mathrm{kg}$ & $2.74 E+01$ & $1.18 \mathrm{E}+01$ & $2.36 \mathrm{E}+01$ \\
\hline & Cobalt & $12 / 12$ & $\mathrm{mg} / \mathrm{kg}$ & $2.00 \mathrm{E}+00$ & $1.15 \mathrm{E}+00$ & $2.30 \mathrm{E}+00$ \\
\hline & Copper & $12 / 12$ & $\mathrm{mg} / \mathrm{kg}$ & $4.00 \mathrm{E}+00$ & $2.62 \mathrm{E}+00$ & $5.23 \mathrm{E}+00$ \\
\hline & Iron & $12 / 12$ & $\mathrm{mg} / \mathrm{kg}$ & $2.38 \mathrm{E}+04$ & $9.31 E+03$ & $1.86 \mathrm{E}+04$ \\
\hline & Lead & $12 / 12$ & $\mathrm{mg} / \mathrm{kg}$ & $1.30 \mathrm{E}+01$ & $6.60 \mathrm{E}+00$ & $1.32 \mathrm{E}+01$ \\
\hline & Magnesium & $12 / 12$ & $\mathrm{mg} / \mathrm{kg}$ & $4.67 \mathrm{E}+02$ & $1.47 \mathrm{E}+02$ & $2.95 \mathrm{E}+02$ \\
\hline & Manganese & $12 / 12$ & $\mathrm{mg} / \mathrm{kg}$ & $2.39 \mathrm{E}+02$ & $8.28 \mathrm{E}+01$ & $1.66 \mathrm{E}+02$ \\
\hline & Mercury & $10 /, 12$ & $\mathrm{mg} / \mathrm{kg}$ & $8.30 \mathrm{E}-02$ & $3.37 \mathrm{E}-02$ & $6.73 E-02$ \\
\hline & Nickel & $12 / 12$ & $\mathrm{mg} / \mathrm{kg}$ & $4.00 \mathrm{E}+00$ & $2.18 \mathrm{E}+00$ & $4.36 \mathrm{E}+00$ \\
\hline & Potassium & $12 / 12$ & $\mathrm{mg} / \mathrm{kg}$ & $1.91 E+02$ & $9.43 \mathrm{E}+01$ & $1.89 E+02$ \\
\hline & Sodium & $11 / 12$ & $\mathrm{mg} / \mathrm{kg}$ & $7.16 \mathrm{E}+01$ & $2.43 \mathrm{E}+01$ & $4.85 \mathrm{E}+01$ \\
\hline & Vanadium & $12 / 12$ & $\mathrm{mg} / \mathrm{kg}$ & $5.98 \mathrm{E}+01$ & $2.29 \mathrm{E}+01$ & $4.58 \mathrm{E}+0 !$ \\
\hline & Zinc & $12 / 12$ & $\mathrm{mg} / \mathrm{kg}$ & $3.09 \mathrm{E}+01$ & $8.69 \mathrm{E}+00$ & $1.74 \mathrm{E}+01$ \\
\hline \multirow[t]{2}{*}{$\begin{array}{l}\text { Radiological } \\
\text { Indicators } \\
\end{array}$} & Gross Alpha & $9 / 12$ & $\mathrm{pCi} / \mathrm{g}$ & $2.72 \mathrm{E}+01$ & $1.24 \mathrm{E}+01$ & $2.49 \mathrm{E}+0 \mathrm{I}$ \\
\hline & Nonvolatile Betz & $8 / 12$ & $\mathrm{pCi} / \mathrm{g}$ & $1.85 \mathrm{E}+01$ & $9.89 \mathrm{E}+00$ & $1.98 \mathrm{E}+01$ \\
\hline Miscellaneous & $\begin{array}{c}\text { Total petroleum } \\
\text { rocarbo }\end{array}$ & $6 / 12$ & $\mathrm{mg} / \mathrm{kg}$ & $7.56 \mathrm{E}+01$ & $1.65 \mathrm{E}+01$ & $3.30 \mathrm{E}+01$ \\
\hline
\end{tabular}


Table 4. Summary of Analytes Detected in Subsurface $(0-1.2 \mathrm{~m}[0-4 \mathrm{ft}])$ Soils

\begin{tabular}{|c|c|c|c|c|c|c|c|c|}
\hline Analyte Class & Analyte & $\begin{array}{c}\text { Frequency of } \\
\text { Detection }\end{array}$ & Units & $\begin{array}{c}\text { Maximum } \\
\text { Detection }\end{array}$ & \begin{tabular}{|l|} 
Average \\
Detection
\end{tabular} & $\mathbf{R B C}$ & $\begin{array}{l}2 \times \text { Average } \\
\text { Background }\end{array}$ & $\begin{array}{l}\text { Retained as } \\
\text { USC }(Y / N)\end{array}$ \\
\hline \multirow[t]{2}{*}{ Volatiles } & I, I,I-Trichloroethane & $8 / 11$ & $\mathrm{mg} / \mathrm{kg}$ & $1.03 \mathrm{E}-02$ & $3.58 \mathrm{E}-03$ & $2.70 \mathrm{E}+02$ & $8.06 \mathrm{E}-03$ & $N$ \\
\hline & Tetruchloroethene & $11 / 11$ & $\mathrm{mg} / \mathrm{kg}$ & $1.31 \mathrm{E}-02$ & $5.83 \mathrm{E}-03$ & $1.20 \mathrm{E}+01$ & $1.42 \mathrm{E}-02$ & $N$ \\
\hline \multirow[t]{14}{*}{ Semivolatiles } & Acenaphthene & $1 / 12$ & $\mathrm{mg} / \mathrm{kg}$ & $1.00 \mathrm{E}-01$ & $1.52 \mathrm{E}-02$ & $4.70 \mathrm{E}+02$ & $1.50 \mathrm{E}-02$ & $N$ \\
\hline & Anthracene & $1 / 12$ & $\mathrm{mg} / \mathrm{kg}$ & $2.30 \mathrm{E}-01$ & $2.65 \mathrm{E}-02$ & $2.30 \mathrm{E}+03$ & $2.08 \mathrm{E}-02$ & $N$ \\
\hline & Benzo(a)anthracene & $1 / 12$ & $\mathrm{mg} / \mathrm{kg}$ & $5.03 \mathrm{E}-01$ & $5.1 \mathrm{IE}-02$ & 88OFAI & $\triangle 45 F \Omega)$ & $N$ \\
\hline & \multicolumn{2}{|l|}{$\begin{array}{c}\text { rene } \\
\end{array}$} & $\mathrm{g} / \mathrm{k}$ & & & & & \\
\hline & \multicolumn{2}{|l|}{$\mathrm{nzo}$} & $m g / k$ & & & & & \\
\hline & \multicolumn{3}{|l|}{ 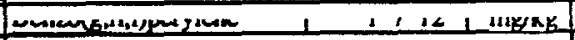 } & \multirow[t]{2}{*}{$4.010-011$} & & & & \\
\hline & \multicolumn{2}{|l|}{ Be zol $k^{\prime \prime}$ orant } & $g / k$ & & & $\infty$ & -02 & $N$ \\
\hline & \multicolumn{2}{|l|}{ Chrysene } & $g / \mathbf{k}$ & & & & & \\
\hline & \multirow{2}{*}{\multicolumn{2}{|c|}{\begin{tabular}{|l} 
Dibenzofuran \\
Fluomnthene
\end{tabular}}} & $m \& / k$ & & & & & \\
\hline & & $2 / 12$ & $\mathrm{mg} / \mathrm{k}$ & & & & & \\
\hline & \multicolumn{2}{|l|}{ Fluorene } & $\mathrm{mg} / \mathrm{kg}$ & $1.02 \mathrm{E}-01$ & $1.5 \mathrm{RF} \Omega \Omega=$ & $21.0 \mathrm{E}+02$ & $1.60 E-02$ & $N$ \\
\hline & Indeno $(1,2,3-\mathrm{c}, \mathrm{d})$ pyrene & $1 / 12$ & $\mathrm{mg} / \mathrm{kg}$ & $2.22 \mathrm{E}-01$ & $2.68 \mathrm{E}-02$ & $8.80 \mathrm{E}-01$ & $2.75 \mathrm{E}-02$ & $N$ \\
\hline & \multirow{2}{*}{\begin{tabular}{|l|} 
Phenanthrene \\
Pyrese \\
\end{tabular}} & 1112 & $\mathrm{mg} / \mathrm{kg}$ & $9.48 \mathrm{E}-01$ & $8.59 \mathrm{E}-02$ & $3.10 \mathrm{E}+02$ & $4.24 \mathrm{E}-02$ & $N$ \\
\hline & & $2 / 12$ & $\mathrm{mg} / \mathrm{kg}$ & $8.95 \mathrm{E}-01$ & $8.67 \mathrm{E}-02$ & $2.30 \mathrm{E}+02$ & $6.90 \mathrm{E}-02$ & $\mathrm{~N}$ \\
\hline Pesticides/PCBs & Aroclor $1260^{6}$ & $2 / 12$ & $\mathrm{mg} / \mathrm{kg}$ & $6.76 \mathrm{E}-02$ & $1.47 \mathrm{E}-02$ & $8.30 \mathrm{E}-02$ & $1.10 \mathrm{E}-02$ & $N$ \\
\hline \multirow[t]{21}{*}{ TAL Inorganies } & Aluminum & $12 / 12$ & $\mathrm{mg} / \mathrm{kg}$ & $8.5 \sqrt{E}+03$ & $4.62 E+03$ & $7.80 \mathrm{E}+03$ & $1.57 E+04$ & $\mathrm{~N}$ \\
\hline & Antimony & $2 ! 12$ & $\mathrm{mg} / \mathrm{kg}$ & $2.00 \mathrm{E}+00$ & $3.81 \mathrm{E}-01$ & $3.10 \mathrm{E}+00$ & $7.48 \mathrm{E}-01$ & $\bar{N}$ \\
\hline & \multicolumn{2}{|l|}{ Arsenic } & $\mathrm{mg} / \mathrm{kg}$ & $2.20 \mathrm{E}+00$ & $1.07 E+00$ & $4.30 \mathrm{E}-01$ & $5.13 E+00$ & $\mathbf{N}$ \\
\hline & \multicolumn{2}{|l|}{ Barium } & $\mathrm{mg} / \mathrm{kg}$ & $3.49 \mathrm{E}+01$ & $1.98 \mathrm{E}+01$ & $5.50 \mathrm{E}+02$ & $4.35 \mathrm{E}+01$ & $\mathrm{~N}$ \\
\hline & \multicolumn{2}{|l|}{ Bervllium } & $\mathrm{mg} / \mathrm{kg}$ & $3.52 \mathrm{E}-01$ & I.49E-0I & $1.50 \mathrm{E}-01$ & $4.21 \mathrm{E} \cap 1$ & $\mathrm{~N}$ \\
\hline & \multicolumn{2}{|l|}{ Cadmium } & $\mathrm{mg} / \mathrm{kg}$ & $1.50 \mathrm{E}+00$ & \begin{tabular}{|c|}
$3.23 E-01$ \\
\end{tabular} & $3.90 \mathrm{E}+00$ & $6.54 E-01$ & $N$ \\
\hline & \multicolumn{2}{|l|}{ Calcium } & $\mathrm{mg} / \mathrm{kg}$ & 2710.09 & inne.met & $=N^{2}$ & $8.92 E+02$ & $N$ \\
\hline & \multicolumn{2}{|l|}{ Chromium } & $\mathrm{mg} / \mathrm{kg}$ & $7.20 \mathrm{E}+00$ & $5.00 \mathrm{E}+00$ & $3.90 \mathrm{E}+01$ & $2.36 \mathrm{E}+01$ & $N$ \\
\hline & \multicolumn{2}{|l|}{ Cobalt } & $\mathrm{mg} / \mathrm{kg}$ & $1.50 \mathrm{E}+00$ & $7.97 \mathrm{E}-01$ & $4.70 \mathrm{E}+02$ & $2.30 \mathrm{E}+00$ & $N$ \\
\hline & \multicolumn{2}{|l|}{ Copper } & $\mathrm{mg} / \mathrm{kg}$ & $1.21 \mathrm{E}+01$ & $3.70 \mathrm{E}+00$ & $3.10 \mathrm{E}+02$ & $5.23 \mathrm{E}+00$ & $N$ \\
\hline & \multicolumn{2}{|l|}{ Cyanide } & $\mathrm{mg} / \mathrm{kg}$ & $2.70 \mathrm{E}-01$ & $6.50 \mathrm{E}-02$ & $1.60 \mathrm{E}+02$ & $8.00 \mathrm{E}-02$ & $\mathrm{~N}$ \\
\hline & Iron & $12 / 12$ & $\mathrm{mg} / \mathrm{kg}$ & $4.80 \mathrm{E}+03$ & $2.59 \mathrm{E}+03$ & $2.30 \mathrm{E}+03$ & $1.86 \mathrm{E}+04$ & $\mathrm{~N}$ \\
\hline & Lead & $11 / 12$ & $\mathrm{mg} / \mathrm{kg}$ & $1.30 \mathrm{E}+01$ & $6.54 \mathrm{E}+00$ & $4.00 \mathrm{E}+02$ & $1.32 \mathrm{E}+01$ & $N$ \\
\hline & Magnesium & $12 / 12$ & mg/kg & $1.15 \mathrm{E}+02$ & $7.88 \mathrm{E}+01$ & $\mathrm{EN}$ & $2.95 E+02$ & $N$ \\
\hline & Manganese & $12 / 12$ & $\mathrm{mg} / \mathrm{kg}$ & $6.99 \mathrm{E}+01$ & $2.52 \mathrm{E}+01$ & $1.80 \mathrm{E}+02$ & $1.66 \mathrm{E}+02$ & $\mathbf{N}$ \\
\hline & Mercury & $12 / 12$ & me/kg & $5.60 \mathrm{E}-02$ & $2.99 \mathrm{E}-02$ & $2.30 \mathrm{E}+00$ & $6.73 \mathrm{E}-02$ & $N$ \\
\hline & Nickel & $12 / 12$ & $\mathrm{mg} / \mathrm{kg}$ & $2.60 \mathrm{E}+00$ & $1.85 E+00$ & $1.60 \mathrm{E}+02$ & $4.36 E+00$ & $\mathbf{N}$ \\
\hline & Potassium & $12 / 12$ & $\mathrm{mg} / \mathrm{kg}$ & $1.41 \mathrm{E}+02$ & $8.28 \mathrm{E}+01$ & EN & $1.89 \mathrm{E}+02$ & $\mathbf{N}$ \\
\hline & Sodium & $9 / 12$ & $\mathrm{mg} / \mathrm{kg}$ & $2.70 E+01$ & $1.68 \mathrm{E}+0 \mathrm{I}$ & $\mathrm{EN}$ & $4.85 \mathrm{E}+01$ & $\mathbf{N}$ \\
\hline & \begin{tabular}{|l} 
Vanadium \\
\end{tabular} & $12 / 12$ & mg/kg & $1.25 \mathrm{E}+01$ & $6.95 \mathrm{E}+00$ & $5.50 \mathrm{E}+01$ & $4.58 \mathrm{E}+01$ & $N$ \\
\hline & Zinc & 12112 & $\mathrm{mg} / \mathrm{kg}$ & $6.46 \mathrm{E}+01$ & $1.45 \mathrm{E}+01$ & $2.30 \mathrm{E}+03$ & $1.74 \mathrm{E}+01$ & $\mathrm{~N}$ \\
\hline Radiological & Gross Alpha & $8 / 12$ & $\mathrm{pCi} / \mathrm{g}$ & $1.46 \mathrm{E}+01$ & $7.66 \mathrm{E}+00$ & $\mathrm{NR}^{\mathrm{z}}$ & $2.49 \mathrm{E}+\Omega !$ & $\bar{N}$ \\
\hline & Nonvolatile Beta & $61^{1} 2^{1 n}$ & $\widehat{p L} / g$ & $1.59 \mathrm{E}+01^{\circ}$ & $8: 41 E+00$ & NR & $1.98 E+01$ & Ni \\
\hline Miscellaneous & $\begin{array}{l}\text { Total } \\
\text { hydrocarbons }\end{array}$ & $9 / 12$ & $\mathrm{mg} / \mathrm{kg}$ & $5.30 \mathrm{E}+02$ & $1.03 \mathrm{E}+02$ & $N A^{4}$ & $3.30 \mathrm{E}+01$ & $N$ \\
\hline
\end{tabular}

Notes

1) A value equal to $2 X$ one-half the laborutory method detection limit is used for constituents not detected in the background population. Analytes not detected in background samples are shown in italics.

2) (a) Risk Based Concentrations for residential soil are from EPA Region III. April 1996. Values for mdiological indicators are from Nix (1996). Value for total recoverable lead is EPA Region IV action limit.

(b) A value of zero is used for essential nutrients and analyres with no reponed RBC.

3) USC for unit-specific contaminant (exceeds both iwice averaze background and RBC)

4). RBC for Pyrene used as a surrogane value.

5) RBC for Fiuorene used as a surrogate value.

6) RBC for Polychiorinated Biphenyl (PCB) used as surrogate value.

7) EN = Essential nutrient

8) $\mathrm{NR}=\mathrm{Nor}$ reponed

9) NA $=$ Not applicable 


\section{Figure 5 MSSB Unit Characterization Locations}

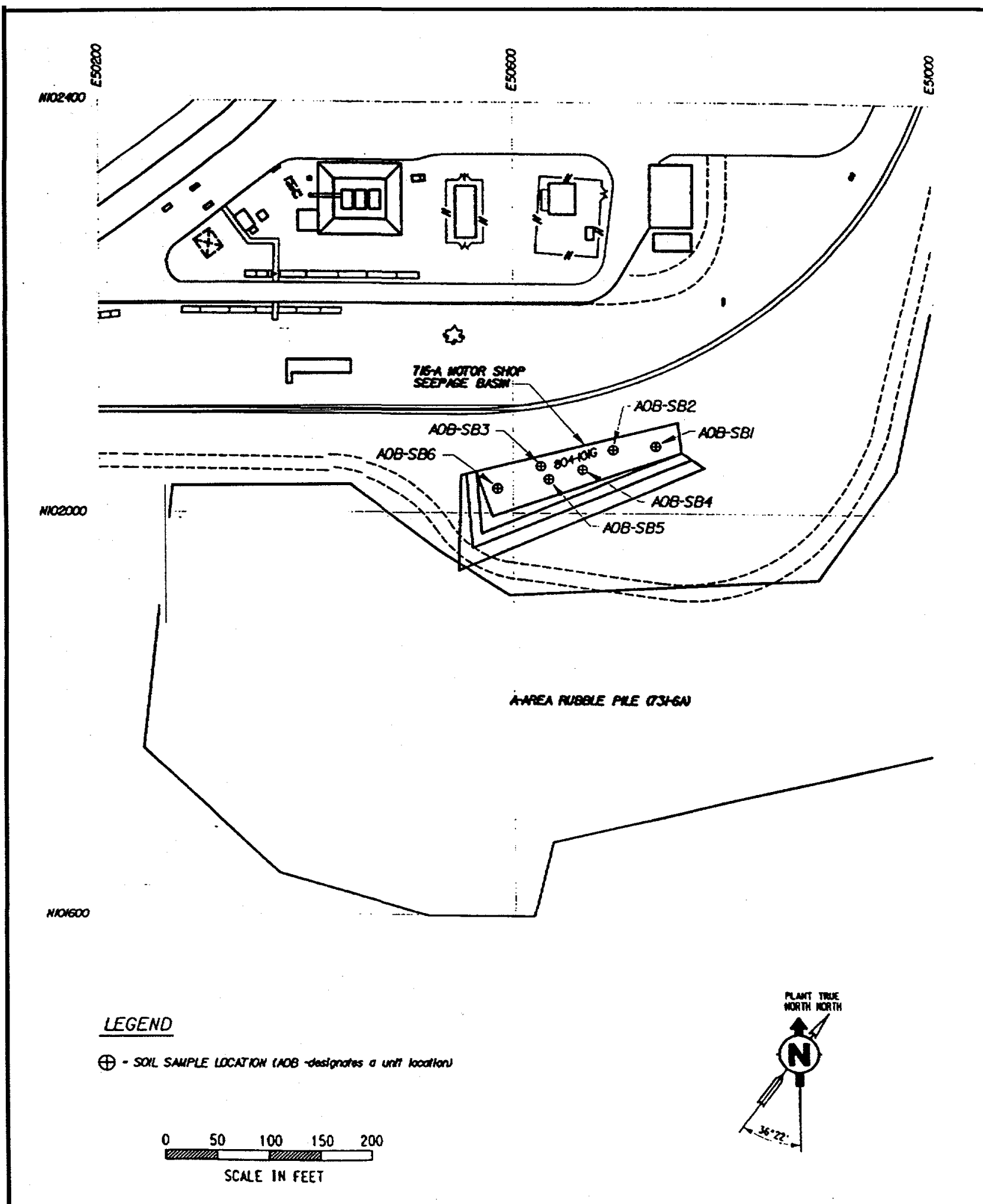




\section{Soils}

The only USC identified for the MSSB was benzo(a)pyrene, which was detected in one of 12 soil samples at a concentration exceeding both its RBC and twice average background level.

Polynuclear Aromatic Hydrocarbons (PAHs), such as benzo(a)pyrene, can be derived from oil, coal, charcoal, or other similar substances and may be of anthropogenic or natural origin. They are not very mobile and tend to readily adsorb to soils. Based on the disposal history of the MSSB, this occurrence of benzo(a)pyrene may be unit related. However, the compound's limited frequency of detection in MSSB soils, together with the unit's proximity to a railroad known to carry coal strongly suggests another possible source for this contamination.

\section{Soil Leachability}

For the purpose of soil leachability analysis, contaminant migration constituents of potential concern are defined as constituents detected in unit soils with a maximum concentration greater than twice their average background level. Two inorganic contaminant migration constituents of potential concern (antimony and cadmium) and three organic contaminant migration constituents of potential concern (benzo(a)anthracene, benzo(g,h,i)perylene, and phenanthrene) are retained for soil leachability equations.

Soil leachability calculations were performed using detailed, unit-specific equations in accordance with EPA soil screening guidance. The equations estimate the concentrations of the contaminant migration constituents of potential concern at the base of the vadose zone. Groundwater concentrations were then calculated from these values by applying a groundwater dilution factor. The nature of the input data and the analytical equation assumptions were such that the estimates of groundwater concentrations were conservative.

Based on the results of the equations, none of the organic contaminant migration constituents of potential concern were predicted to leach into groundwater and none of the inorganic contaminant migration constituents of potential concern were estimated to reach maximum concentration within 1000 years. Therefore, none of the contaminant migration constituents of potential concern calculated for the MSSB are likely to pose a future human health risk due to ingestion of groundwater.

\section{SUMMARY OF OPERABLE UNIT RISKS}

As a component of the remedial investigation process, a baseline risk assessment was prepared for the MSSB. The baseline risk assessment consists of human health and ecological risk assessments. The risks calculated are based on the levels of benzo(a)pyrene detected for human health at MSSB because this is the only constituent to remain as a preliminary constituent of concern. Uncertainty analysis determined that benzo(a)pyrene is not unit related and the conservative risk methodology used in the Baseline Risk Assessment likely overstated the actual risk reported attributable to benzo(a)pyrene. The following describes the risk levels attributable to benzo(a)pyrene.

Carcinogenic risks are estimated as the incremental probability of an individual developing cancer over a lifetime as a result of pathway-specific exposure to cancer-causing contaminants. The risk to an individual resulting from exposure to non-radioactive chemical carcinogens is expressed as the increased probability of cancer occurring over the course of a 70 year lifetime. Cancer risks are related to the EPA target risk range of one in ten thousand $\left(1 \times 10^{-4}\right)$ to one in one million $\left(1 \times 10^{-6}\right)$ for incremental cancer risk at NPL sites. Risk levels in the $1 \times 10^{-4}$ to $1 \times 10^{-6}$ range require a risk management decision where specific actions to reduce risk may be considered while cancer risk levels below $1 \times 10^{-6}$ are considered to be insignificant. 
Non-carcinogenic effects are also evaluated to identify a level at which there may be concern for potential noncarcinogenic health effects. The hazard quotient, which is the ratio of the expasure dose to the reference dose (RfD), is calculated for each contaminant. Hazard quotients are summed for each exposure pathway to determine the specific hazard index (HI) for each exposure scenario. If the HI exceeds unity (1.0), the potential exists that adverse health effects might occur.

Summary information for the human health and ecological risk assessments is discussed in the following sections.

\section{Summary of Human Health Risk Assessment}

\section{Current Land Use Results}

Under the current land use scenario, carcinogenic risks and noncarcinogenic hazards are characterized for exposure of an on-unit worker to soil. Known on-unit workers are expected to be exposed to surface soils $(0-0.3 \mathrm{~m} \mathrm{[0-1} \mathrm{ft}])$. Figure 6 summarizes the risks and hazards graphically. Table 5 summarizes both the current and future land use scenarios for surface soil. Table 6 summarizes both the current and future land use scenarios for subsurface soil.

\section{Noncarcinogenic Hazard}

There are no noncarcinogenic $H I$ values for the known on-unit worker exposure pathways because reference dose values for noncancer effects are not available for benzo(a)pyrene, the only unit constituent of concern.

\section{Carcinogenic Risk}

All of the estimated total cancer risks are less than $1 \times 10^{-6}$, indicating that, under current conditions, carcinogenic risk is insignificant at the unit. For the $0-0.3 \mathrm{~m}(0-1 \mathrm{ft})$ soil interval, the total cancer risk for the known on-unit worker is $1 \times 10^{-8}$. 
Figure 6.

Summary of Risks and Hazards for the MSSB Surface Soil (0-0.3 m) Pathway for the Known On-Unit Worker
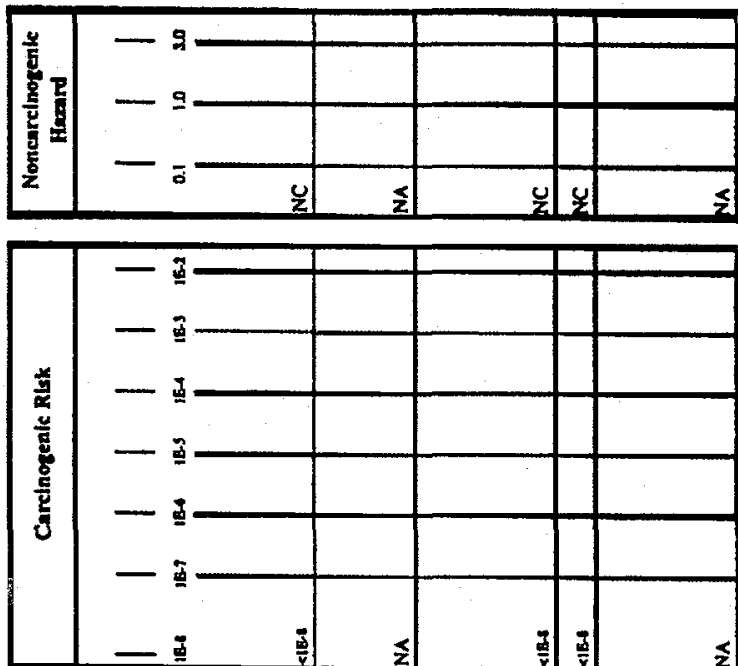

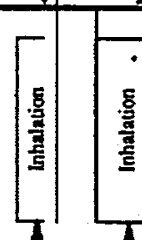

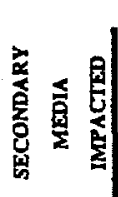

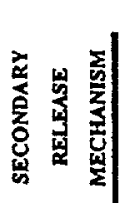

妾 1
8
5
5
5

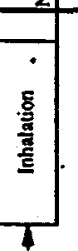

$\frac{1}{2}$

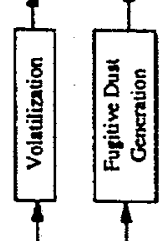

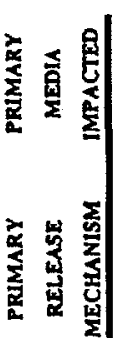

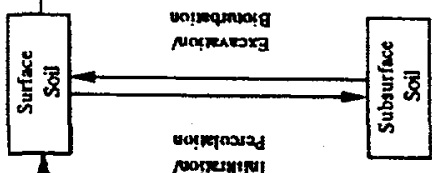

soprenty
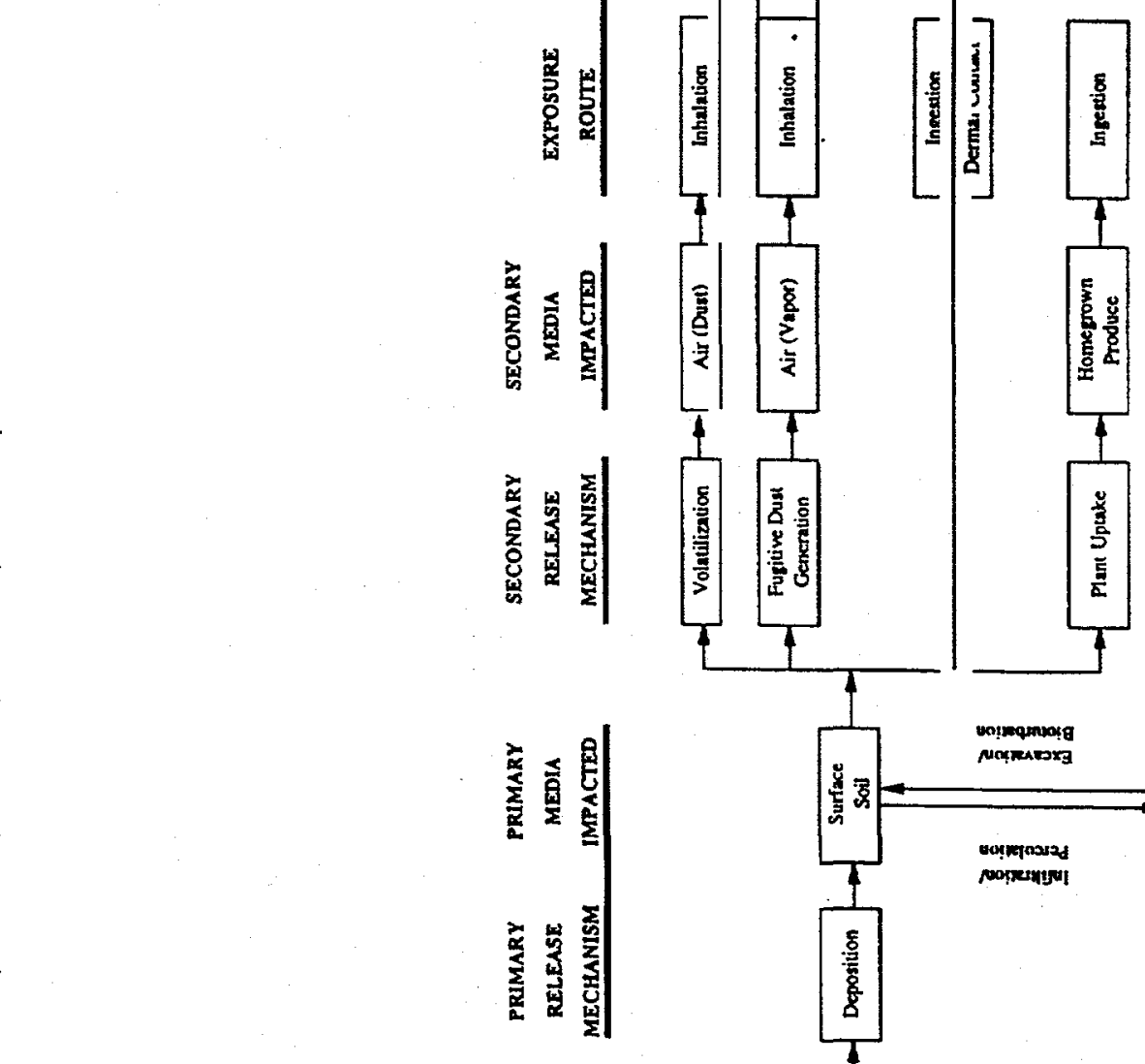

洁

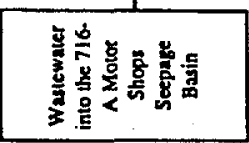


Table 5.

RME Risk Characterization Summary, Surface Soil (Depth 0-0.3 $\mathrm{m}$ [ $[0$ to $1 \mathrm{ft}]$ ) at the
Motor Shops Seepage Basin
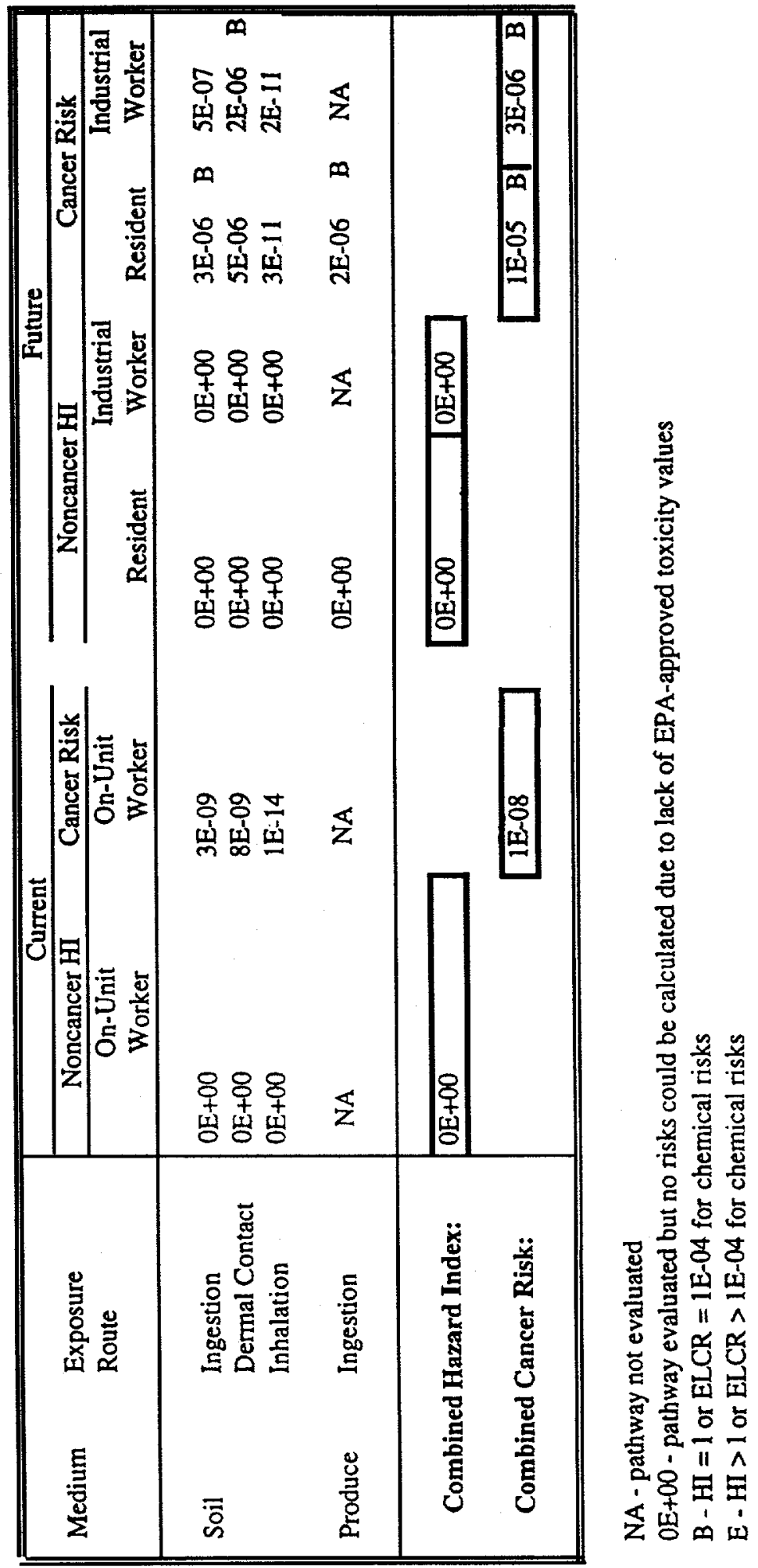
Table 6.

RME Risk Characterization Summary, Subsurface Soil (Depth 0-1.2 $\mathrm{m}[0$ to $4 \mathrm{ft}])$ at the Motor Shops Seepage Basin
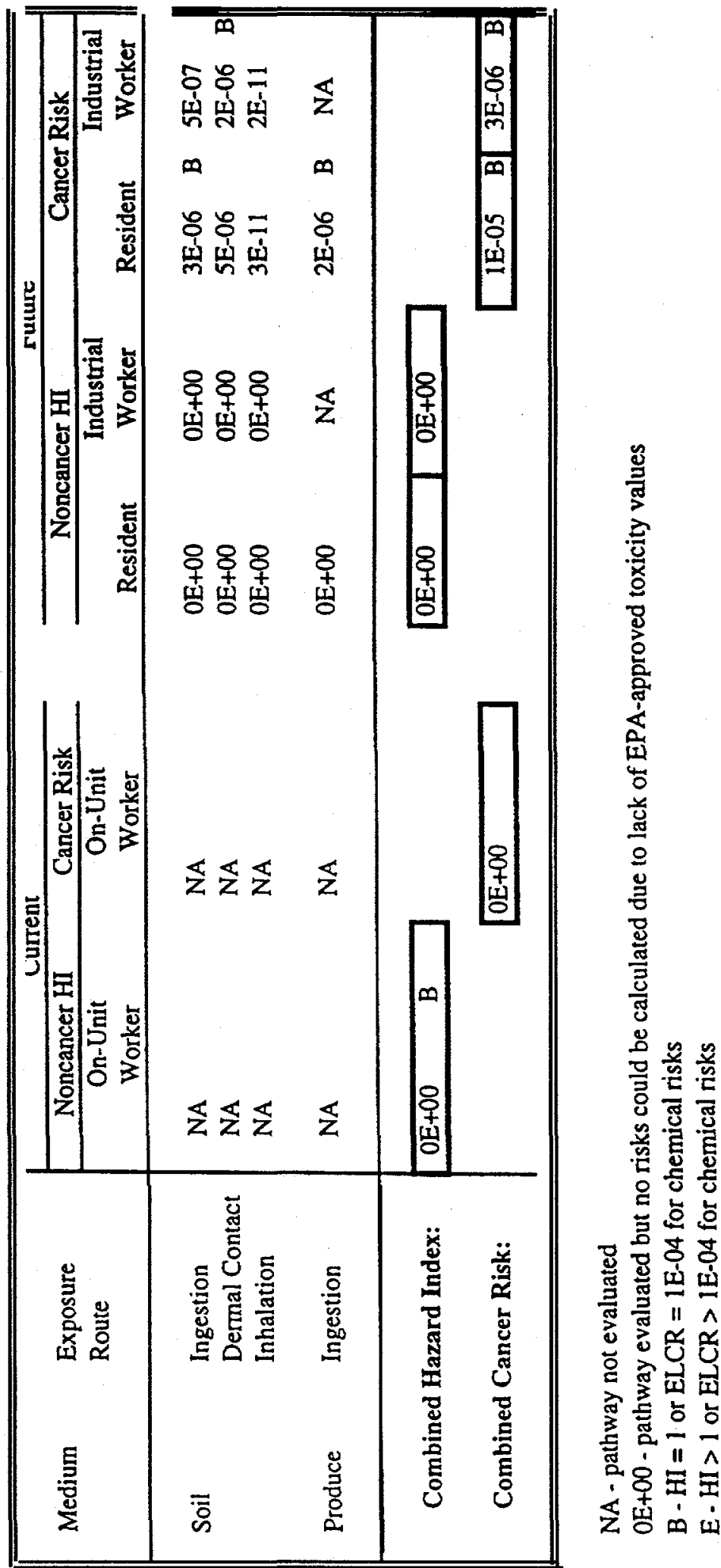


\section{Future Land Use Results}

The future hypothetical on-unit workers are assumed to be exposed to surface soils $(0-0.3 \mathrm{~m}[0-1 \mathrm{ft}])$ and subsurface soils $(0-1.2 \mathrm{~m}[0-4 \mathrm{ft}])$. Figures 7 and 8 summarize the risks and hazards graphicall $y$ for the Hypothetical On-Unit Industrial Worker.

\section{Hypothetical On-Unit Industrial Worker}

Under the future land use scenario, carcinogenic risks and noncarcinogenic hazards are calculated for exposure of the hypothetical on-unit worker to surface soils, redistributed subsurface soils, but not to homegrown produce.

\section{Noncarcinogenic Hazard}

There are no noncarcinogenic HIs for the hypothetical on-unit worker exposure pathways because reference dose values for noncancer effects are not available for benzo(a)pyrene, the only unit constituent of potential concern.

\section{Carcinogenic Risk}

For the $0-0.3 \mathrm{~m}(0-1 \mathrm{ft})$ and the $0-1.2 \mathrm{~m}(0-4 \mathrm{ft})$ soil intervals, the total cancer risk for the hypothetical on-unit industrial worker is $3 \times 10^{-6}$. The risk is from benzo(a)pyrene in the dermal contact pathway. 
Record of Decision for the Motor Shops Seepage Basin (716-A)(U)

Savannah River Site

WSRC-RP-97-840

April 1998

Revision 0

Page 21 of 30

Figure 7. Summary of Risks and Hazards for the MSSB Surface Soil $(0-0.3 \mathrm{~m})$ Pathway for the Hypothetical Industrial Worker
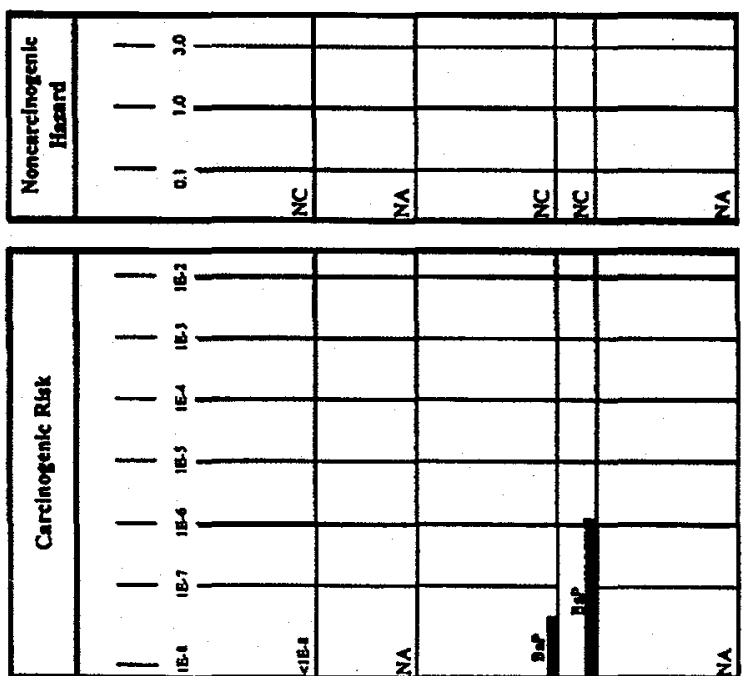

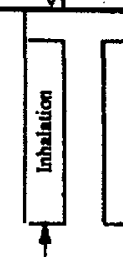

递密育

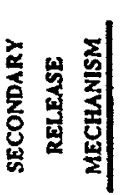

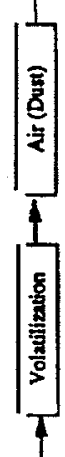

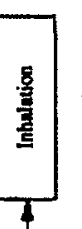

年

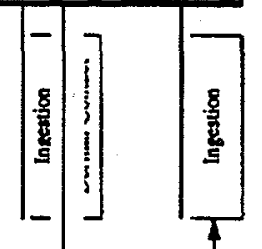

-

-

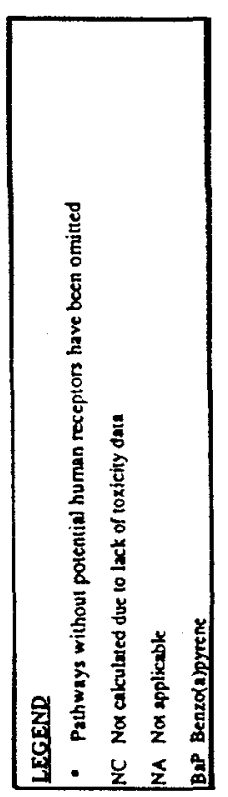


Figure 8. Summary of Risks and Hazards for the MSSB Subsurface Soil (0-1.2 $\mathrm{m})$ Pathway for the Hypothetical Industrial Worker
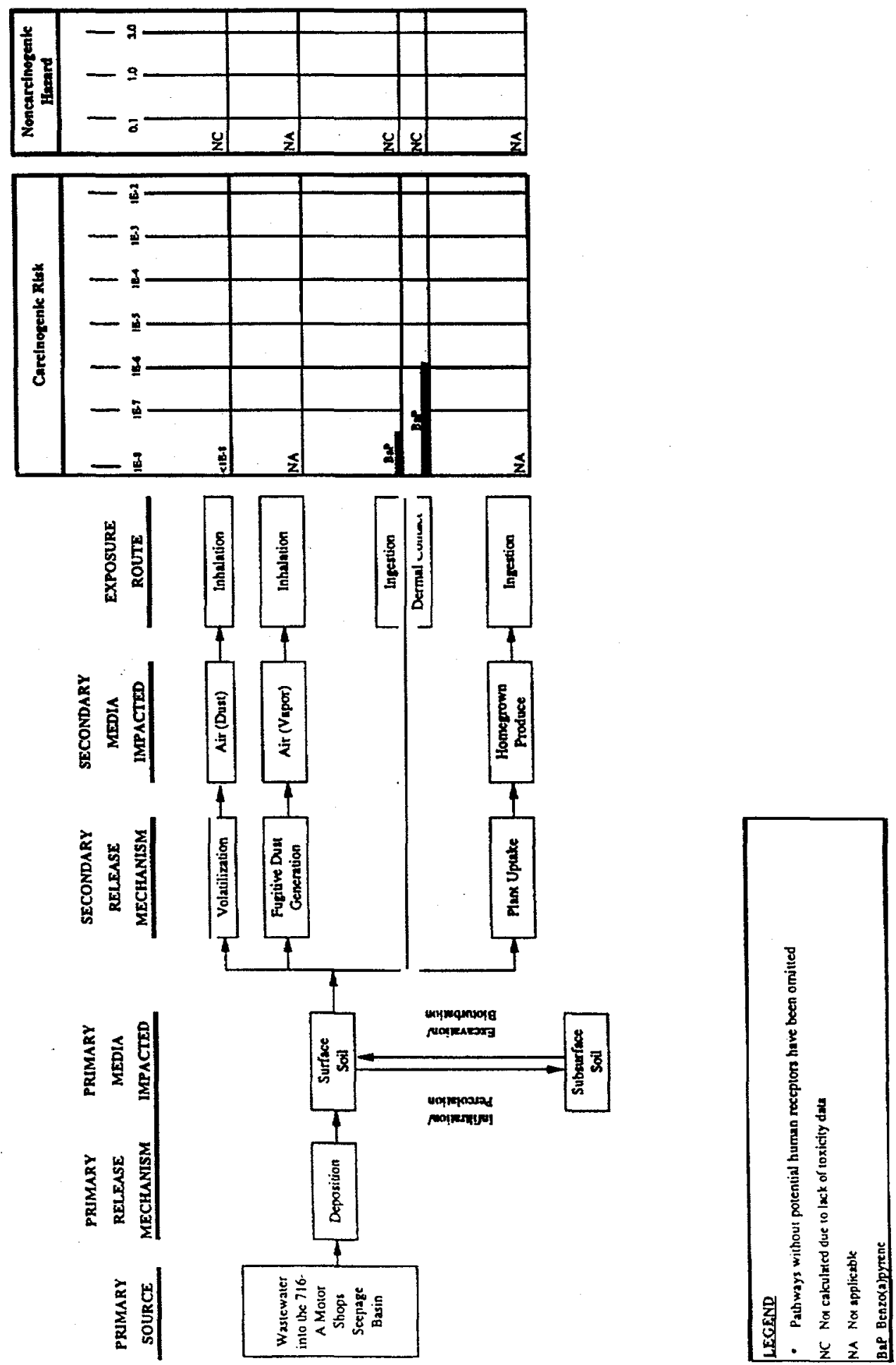


\section{Hypothetical On-Unit Resident}

The future hypothetical on-unit residents are assumed to be exposed to surface soils $(0-0.3 \mathrm{~m}[0-1 \mathrm{ft}])$ and subsurface soils $(0-1.2 \mathrm{~m}$ [0-4 ft]). Hypothetical residents are also assumed to be exposed to homegrown produce. Figures 9 and 10 summarize the risks and hazards graphically for the Hypothetical Adult/Child Resident.

\section{Noncarcinogenic Hazard}

There are no noncarcinogenic HIs for the hypothetical on-unit resident exposure pathways because reference dose values for noncancer effects are not available for benzo(a)pyrene, the only unit constituent of potential concern.

\section{Carcinogenic Risk}

For the $0-0.3 \mathrm{~m}(0-1 \mathrm{ft})$ soil interval, the total cancer risk for the hypothetical on-unit resident is $1 \times 10^{-5}$. This is below $1 \times 10^{-4}$, but exceeds the initial level of concern for cancer risk $\left(1 \times 10^{-6}\right)$. Pathways with cancer risks greater than $1 \times 10^{-6}$ include soil ingestion (Excess Lifetime Cancer Risk [ELCR] $=3 \times 10^{-6}$ ), dermal contact $\left(5 \times 10^{-6}\right)$, and ingestion of produce $\left(2 \times 10^{-6}\right)$ grown in the soil. Benzo(a)pyrene, which is a secondary constituent of concern, is the only constituent of concern identified for the $0-0.3 \mathrm{~m}(0-1 \mathrm{ft})$ soil interval.

For the 0-1.2 $\mathrm{m}(0-4 \mathrm{ft})$ soil interval, the total cancer risk for the hypothetical on-unit resident is $1 \times 10^{-5}$. This is below $1 \times 10^{-4}$, but exceeds the initial level of concern for cancer risk $\left(1 \times 10^{-6}\right)$. Pathways with cancer risks greater than $1 \times 10^{-6}$ include soil ingestion $\left(E L C R=3 \times 10^{-6}\right)$, dermal contact $\left(5 \times 10^{-6}\right)$, and ingestion of produce $\left(2 \times 10^{-6}\right)$ grown in the soil. Benzo(a)pyrene, which is a secondary constituent of concern, is the only constituent of concern identified for the 0-1.2 m (0-4 ft) soil interval. 
Figure 9.

Summary of Risks and Hazards for the MSSB Surface Soil (0-0.3 m) Pathway for the Hypothetical Adult/Child Resident
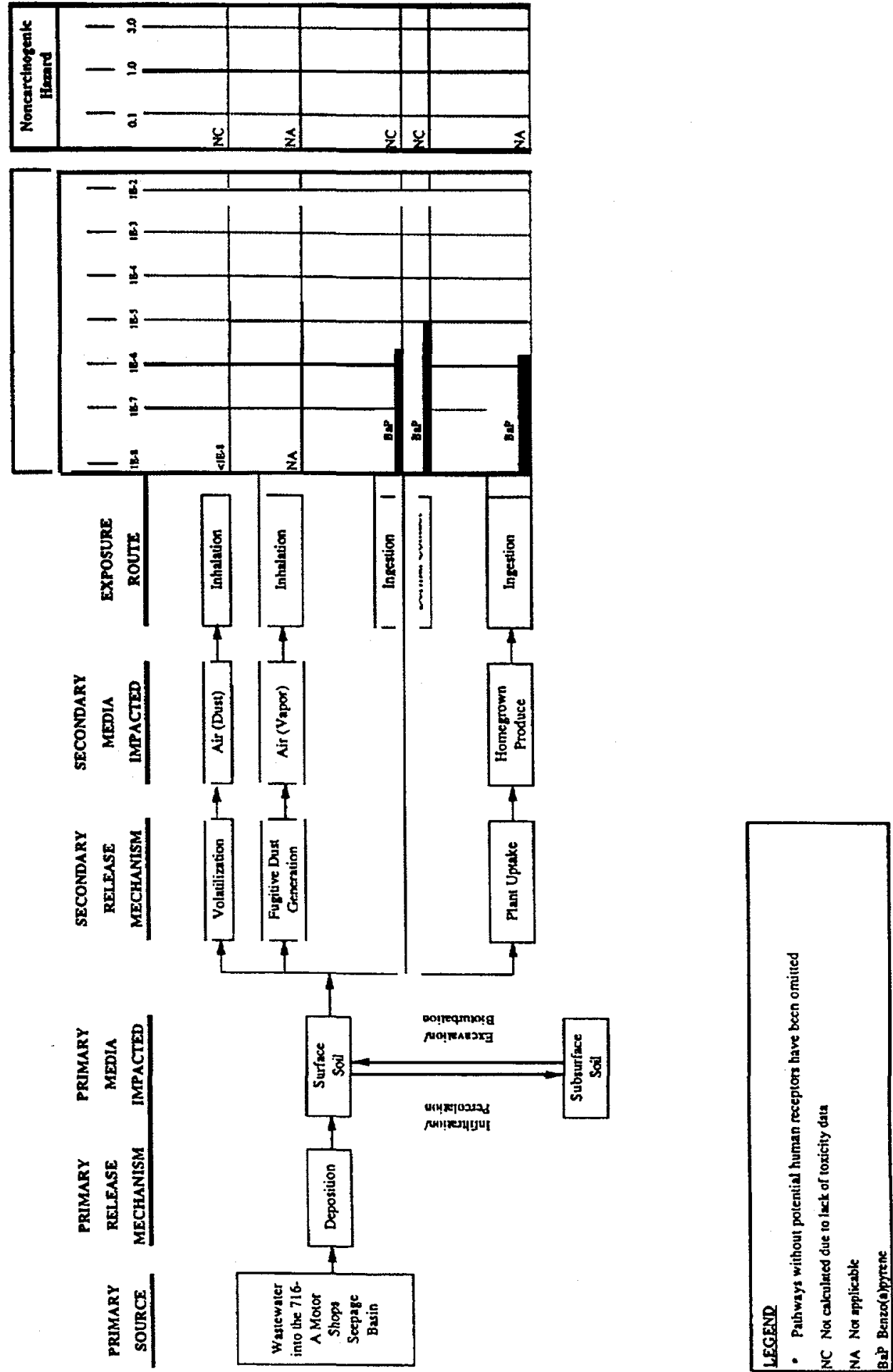


\section{Figure 10.}

Summary of Risks and Hazards for the MSSB Subsurface Soil (0-1.2 m) Pathway for the Hypothetical Adult/Child Resident
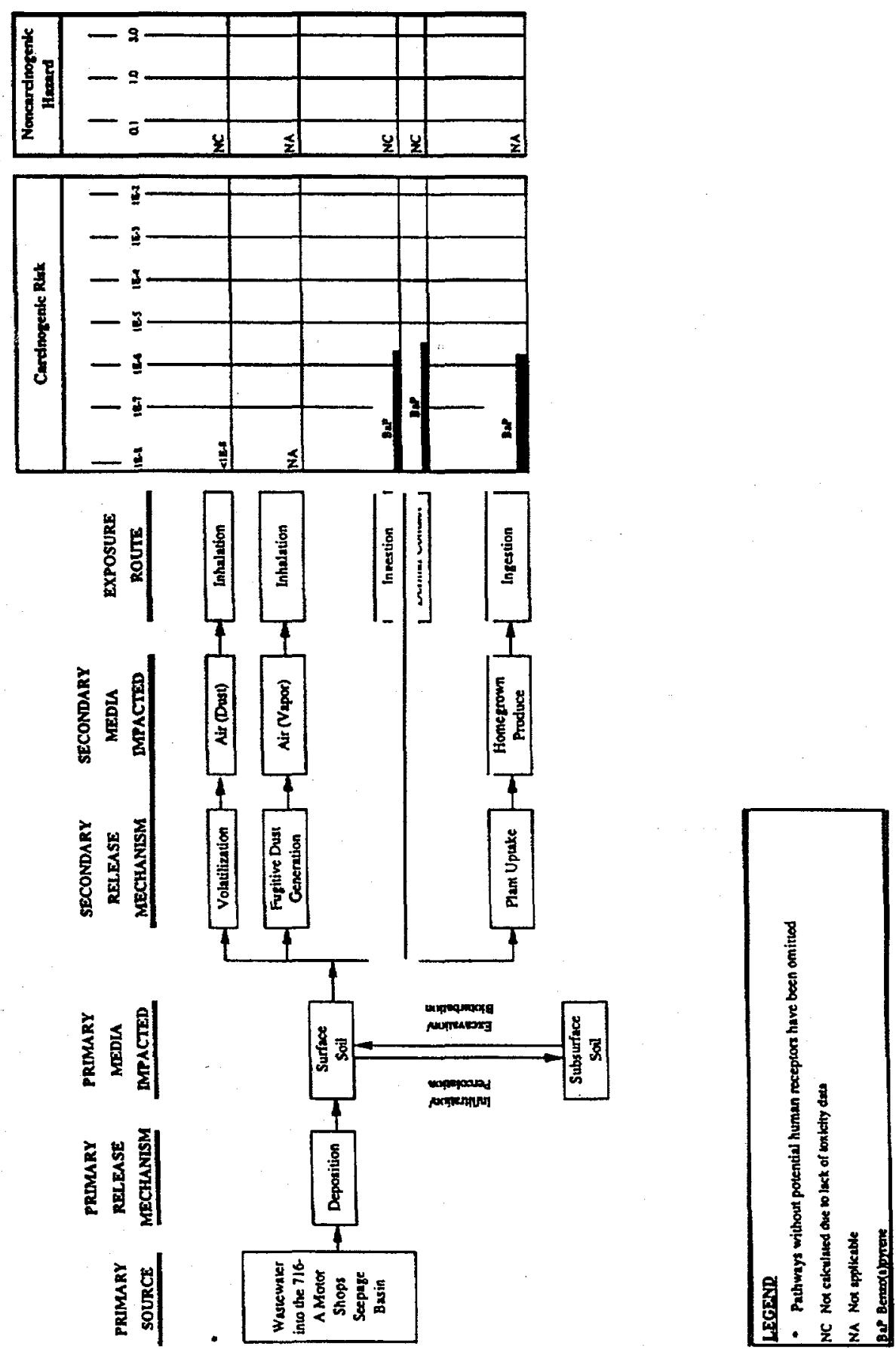


\section{Summary of Ecological Risk Assessment}

The purpose of the ecological risk assessment (ERA) component of the Baseline Risk Assessment is to evaluate the likelihood that adverse ecological effects may occur or are occurring as a result of exposure to unit-related constituents based on a weight-of-evidence approach. An ecological risk does not exist unless a given constituent has the ability to cause one or more adverse effects and it either co-occurs with, or is contacted by, an ecological receptor for a sufficient length of time or at a sufficient intensity to elicit the identified adverse effect(s).

The assessment endpoint at the MSSB is the maintenance of the terrestrial ecosystem, with no loss of species or community alteration due to antimony or cadmium toxicity, the only ecological constituents of potential concern. The testable hypothesis is that the reasonable maximum exposure (RME) concentrations of antimony and cadmium present in surface and subsurface soils are not toxic to terrestrial animals at the unit. To verify or recant the testable hypothesis, a receptor species, the oldfield mouse, is selected to represent the assessment endpoint. Since it is unlikely that antimony bioaccumulates or cadmium biomagnifies in the food chain, direct measurement of antimony and cadmium concentrations in soil media, to be modeled to concentrations in the oldfield mouse, is selected as the appropriate measurement endpoint.

The ERA confirms that the RME concentrations of antimony and cadmium present in soils at the unit are not toxic to terrestrial animals at the unit. No ecological constituents of concern are identified at the MSSB waste unit. No hazard quotients (HQs) at the MSSB are greater than 1. The constituents detected in surface and subsurface soils at the unit do not pose unacceptable risk, do not threaten the assessment endpoint for the unit, and do not impact the policy goal applicable to the unit.

\section{Uncertainty}

Benzo(a)pyrene is the only human health preliminary constituent of concern detected in surface soils $(0-0.3 \mathrm{~m}$ [0-1 ft] interval). It exceeds human health risk-based criteria (highest risk $=1 \times 10^{-5}$ for the hypothetical adult/child receptor); the dermal pathway is the most significant risk contributor, $5 \times 10^{-6}$. Benzo(a)pyrene was not detected in the subsurface soils greater than $0.3 \mathrm{~m}(1 \mathrm{ft})$. Although benzo(a)pyrene exceeds human health risk-based criteria, it is eliminated from further consideration as a constituent of concern for the following reasons:

- The use of $1 \mathrm{mg} / \mathrm{cm}^{2}$ as the soil-to-skin adherence factor is high, which causes the risk to be high and very conservative in nature.

- When comparing central tendency exposure risk estimates to RME estimates, the combined central tendency exposure estimates are an order of magnitude lower than the RME estimates for both the industrial worker and the adult/child receptors. Risks are probably significantly overestimated by using the RME value and a high soil adherence factor. The central tendency exposure risk estimates are, by definition, representative of more likely exposures than are the RME estimates.

- Benzo(a)pyrene was detected in one out of six surface (0-1 ft) soil samples and in one out of 12 subsurface soil samples (which includes the $0-0.3 \mathrm{~m}[0-1 \mathrm{ft}]$ interval). Therefore, the frequency of detection is very low.

- Benzo(a)pyrene was detected two out of six times in the background samples for the surface soils. Organics are not screened out based on background comparisons as part of the constituent of potential concern selection process for the risk assessment. 
Since benzo(a)pyrene is eliminated from further consideration as a constituent of concern, no human health remedial goal options are determined for this unit.

\section{Site-Specific Considerations}

Site-specific considerations, based on the conclusions of the Baseline Risk Assessment and RFIRI, which suggest limited or no potential for significant risk include:

No samples were taken from the primary source of contamination (i.e., wastewater) because wastewater is no longer discharged to the seepage basin. The only Unit Specific Constituent (USC) found in the secondary sources of contamination (i.e., surface soil and subsurface soil) was benzo(a)pyrene. Benzo(a)pyrene is a polynuclear aromatic hydrocarbon (PAH). PAHs can be derived from oil, coal, charcoal, or other similar substances and may be of anthropogenic or natural origin. They are not very mobile and tend to readily adsorb to soils. Based on the disposal history of the MSSB, this occurrence of benzo(a)pyrene may be unit related. However, the compound's limited frequency of detection in MSSB soils, together with the unit's proximity to a railroad known to carry coal, strongly suggests another possible source for this contamination.

\section{Remedial Action Objectives}

Remedial action objectives specify unit-specific contaminants, media of concern, potential exposure pathways, and remediation goals. Remediation goals are developed based upon Applicable or Relevant and Appropriate Requirements (ARARs) or can be risk-based. Because there are no constituents of concern at the unit, remedial action objectives are not required.

ARARs are those cleanup standards, standards of control, and other substantive requirements, criteria, or limitations promulgated under federal, state, or local environmental law that specifically address a hazardous substance, pollutant, contaminant, remedial action, location, or other circumstance at a CERCLA site. Other available information that is not an ARAR (e.g., advisories, criteria, guidance) may be considered in the analysis if it helps to ensure protectiveness or is otherwise appropriate for use in a specific alternative. These guidances are referred to as to-be-considered (TBC) guidances. Three types of ARARs; action-, chemical-, and location-specific; have been developed to simplify identification and compliance with environmental requirements. Action-specific requirements set controls on the design, performance and other aspects of implementation of specific remedial activities. Chemical-specific requirements are media-specific, healthbased concentration limits developed for site-specific levels of contaminants in specific media. Locationspecific ARARs must consider federal, state, and local requirements that reflect the physiographical and environmental characteristics of the unit or the immediate area.

The only nonradiological chemical-specific ARARs for soils under Federal and South Carolina regulations are for polychlorinated biphenyls (PCBs) and lead (400 mg/kg). ARARs for PCBs are governed by the Toxic Substances Control Act (40 CFR Part 761). For an unrestricted access area (e.g., residential), the PCB cleanup standard is $1 \mathrm{mg} / \mathrm{kg}$ by weight, provided that the soil is excavated to a minimum depth of $25 \mathrm{~cm}(10 \mathrm{in})$ and that the excavated soil is replaced with clean soil (i.e., soil containing less than $1 \mathrm{mg} / \mathrm{kg}$ PCBs). One PCB, arocior- 1260 , was detected twice in the surface soil interval at a concentration of $6.76 \mathrm{E}-02 \mathrm{mg} / \mathrm{kg}$. This concentration is below both the ARAR and RBC criteria. The maximum detection of lead was only $13 \mathrm{mg} / \mathrm{kg}$ which is well below the $400 \mathrm{mg} / \mathrm{kg}$ limit. 


\section{DECLARATION STATEMENT}

Based on the MSSB RCRA Facility Investigation/Remedial Investigation (RFI/RI) Report, the Baseline Risk Assessment, and the uncertainty analysis, the MSSB poses no significant risk to human health and the environment. The Baseline Risk Assessment determined that there are no constituents of concern present at MSSB, therefore no remedial goals were set and No Action is an appropriate remedy.

The selected remedy is protective of human health and the environment and complies with federal and state requirements that are legally applicable or relevant and appropriate to the remedial action. No Action will not result in hazardous substances, pollutants, or contaminants remaining in the source unit, therefore five-year Record of Decision reviews are not required.

\section{EXPLANATION OF SIGNIFICANT CHANGES}

There were no significant changes made to the Record of Decision based on comments received during the public comment period for the Statement of Basis/Proposed Plan. Comments that were received during the public comment period are addressed in Appendix A.

\section{RESPONSIVENESS SUMMARY}

A Responsiveness Summary of the comments received during the public comment period is included in Appendix A. 


\section{REFERENCES}

DOE (U.S. Department of Energy), 1994. Public Involvement, A Plan for Savannah River Site. Savannah River Operations Office, Aiken South Carolina.

FFA, 1993. Federal Facility Agreement for the Savannah River Site. Administrative Docket No. 89-05-FF, effective date: August 16, 1993, WSRC-OS-94-42.

Huber, L. A., W.F. Johnson, and H. W. Bledsoe, 1987. Environmental Information Document: Waste Oil Basins. DPST-85-701. E.I. du Pont de Nemours and Company, Savannah River Laboratory, Aiken, South Carolina.

Nix, D., 1996. Risk-Based Activity Calculations for Radionuclides: Residential Water Ingestion, Residential Soil Ingestion, and Residential External Radiation Exposure Pathways. WSRC Calculation Number K CLC-G-00023. Savannah River Site, Aiken, South Carolina. November 1996.

WSRC, 1990. RCRA Facility Investigation/Remedial Investigation Plan for the 716-A Motor Shops Seepage Basin. WSRC-RP-90-581. Savannah River Site, Aiken, South Carolina.

WSRC, 1996. RCRA Facility Investigation /Remedial Investigation Work Plan for the 716-A Motor Shops Seepage Basin, Revision 0. WSRC-RP-96-00111. Savannah River Site, Aiken. South Carolina: Westinghouse Savannah River Company.

WSRC, 1997a. RCRA Facility Investigation/Remedial Investigation Report with the Baseline Risk Assessment for the 716-A Motor Shops Seepage Basin (U), WSRC-RP-97-134, Revision 1, Westinghouse Savannah River Company, Aiken, South Carolina (August, 1997).

WSRC, 1997b. Statement of Basis/Proposed Plan for the Motor Shops Seepage Basin (716-A) (U), WSRCRP-97-839, Revision 0, Westinghouse Savannah River Company, Aiken, South Carolina (December 1997). 
Record of Decision for the Motor Shops Seepage Basin (7 16-A) (U)

Savannah River Site

WSRC-RP-97-840

April 1998

Revision 0

Page 30 of 30

This page intentionally left blank. 


\section{APPENDIX A}

\section{RESPONSIVENESS SUMMARY}




\section{RESPONSIVENESS SUMMARY}

The public comment period for the Statement of Basis/Proposed Plan for the Motor Shops Seepage Basin (716A) began on February 12, 1998 and ended on March 28, 1998. The public comment period for the RCRA Permit Modification began on February 12, 1998 and ended on March 28, 1998.

\section{Public Comments}

There were no public comments of the Motor Shops Seepage Basin Statement of Basis/Proposed Plan. 